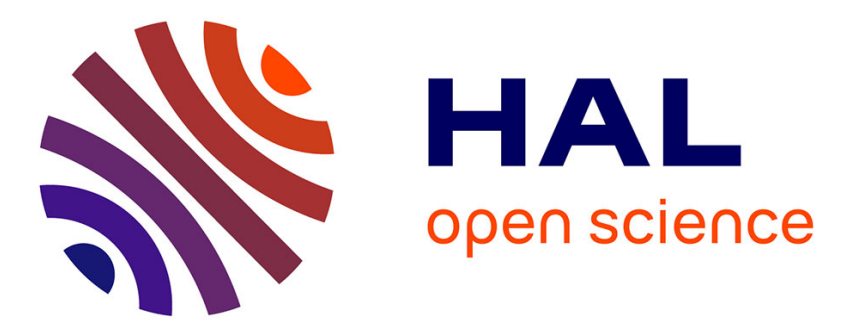

\title{
A review of biology, fisheries and population structure of Dentex dentex (Sparidae)
}

Michel Marengo, Eric D H Durieux, Bernard Marchand, Patrice Francour

\section{To cite this version:}

Michel Marengo, Eric D H Durieux, Bernard Marchand, Patrice Francour. A review of biology, fisheries and population structure of Dentex dentex (Sparidae). Reviews in Fish Biology and Fisheries, 2014, 24, pp.1065-1088. 10.1007/s11160-014-9363-9 . hal-01148892

\section{HAL Id: hal-01148892 \\ https://hal.science/hal-01148892}

Submitted on 5 May 2015

HAL is a multi-disciplinary open access archive for the deposit and dissemination of scientific research documents, whether they are published or not. The documents may come from teaching and research institutions in France or abroad, or from public or private research centers.
L'archive ouverte pluridisciplinaire HAL, est destinée au dépôt et à la diffusion de documents scientifiques de niveau recherche, publiés ou non, émanant des établissements d'enseignement et de recherche français ou étrangers, des laboratoires publics ou privés. 


\section{A review of biology, fisheries and population structure of}

\section{Dentex dentex (Sparidae).}

Michel Marengo ${ }^{1,2}$, Eric D.H. Durieux ${ }^{1,2}$, Bernard Marchand ${ }^{1,2}$, Patrice Francour ${ }^{3}$

${ }^{1}$ University of Corsica Pasquale Paoli, UMR 6134 CNRS-UCPP Science for Environment, 20250 Corte (France)

${ }^{2}$ University of Corsica Pasquale Paoli, UMS 3514 CNRS-UCPP Stella Mare Platform, 20620 Biguglia (France)

${ }^{3}$ University of Nice-Sophia Antipolis, EA 4228 ECOMERS, Science Faculty, 06108 Nice Cedex 2

Corresponding author:

Tel: +33 (0) 420202159

E-mail: marengo@univ-corse.fr 


\section{Abstract}

The common dentex Dentex dentex (Linnaeus, 1758) is an iconic marine coastal fish in the Mediterranean Sea. It is a demersal sparid fish $(0-200 \mathrm{~m})$, that grows to a maximum length of $100 \mathrm{~cm}$ and a weight of $13 \mathrm{~kg}$, with a relatively long life span (more than 20 years). As a high trophic level predator, it holds a key position in the coastal marine food webs. The common dentex is of great economic importance for both artisanal (small-scale coastal fisheries) and recreational fishing. Despite its economic and ecological importance, scientific data on this species in its natural environment are still very scant. The global commercial catch of common dentex has fluctuated over the last sixty years on a multidecadal time scale, and has declined significantly since the 1990s. There are few data regarding fishing effort and total catch from recreational fishing for common dentex, but it appears that this species is particularly targeted by this activity. The common dentex is now classified as "vulnerable" in the Red List of Threatened Species in the Mediterranean Sea. This review summarizes the current literature on $D$. dentex as regards biology, ecology, parasitology, population structure, commercial and recreational fishing, regulation and minimum fish sizes, and management through marine protected areas. It is suggested future research directions to fill the gaps in current knowledge.

Keywords: Dentex dentex, biology, population structure, fisheries, parasitology, conservation. 


\section{Introduction}

The common dentex Dentex dentex (Linnaeus, 1758) is an iconic marine coastal bony fish in the Mediterranean Sea. It holds an important place as a fishery resource for both professional and recreational fishing, and a key position at the top of the food chain in coastal ecosystems. It belongs to the Sparidae family (Bauchot and Hureau 1986), which is represented in the Mediterranean Sea by 10 genera and 22 species that usually inhabit coastal areas (Arculeo et al. 2003). It was first described in the 18th century as Sparus dentex Linnaeus, 1758, then Sparus cetti Risso 1810 or Dentex vulgaris Cuvier \& Valenciennes, 1839 and finally Dentex dentex (Linnaeus, 1758) (Tortonese 1973; Bauchot and Hureau 1986; Bauchot and Hureau 1990). This species is of great economic interest and high commercial value for artisanal fishing (Morales-Nin and Moranta 1997; Loir et al. 2001; Chemmam-Abdelkader et al. 2007). Dentex dentex is considered as a "noble" species given its high market value (Chemmam-Abdelkader et al. 2006). Prices may range from a minimum of $15 € / k g$ for whole fish to a maximum of $38 € / \mathrm{kg}$ for fillets and sliced fish. It is a highly prized catch in recreational fishing (MoralesNin et al. 2005; Font and Lloret 2011); and is also appreciated by scuba divers (Cadiou et al. 2009).

As a top predator, the common dentex occupies a key position at the top of the trophic pyramid, and so is a potential indicator species for the structure and functioning of the coastal ecosystems on which it depends (Macpherson et al. 2002; Seytre \& Francour 2009; Valls et al 2012).

Dentex dentex is classified by the International Union for the Conservation of Nature (IUCN) as "vulnerable" in the Red List of Threatened Species in the Mediterranean Sea (Abdul Malak et al. 2011). There are several reasons for this ranking: the Food and Agriculture Organization (FAO) has reported that landings for this species have steadily declined over a recent 15-year period, from a peak of $\sim 7,000$ tons in 1990 to less than 1,000 tons in 2005. In addition, it is a highly sought-after food fish targeted by recreational fishing. It is relatively long-lived, and its populations are slow to recover. Other "vulnerable" bony fish species in Mediterranean include the dusky grouper Epinephelus marginatus (Lowe, 1834), and the brown meagre Sciaena umbra Linnaeus, 1758, so that D. dentex is the only Sparidae species with this conservation status (Abdul Malak et al. 2011). The common dentex is also considered as a potential candidate for aquaculture, due to its commercial success, ease of reproduction in captivity and high growth rates during the first years (Abellán 2000; Loir et al. 2001; Rueda and Martinez 2001; Giménez and Estévez 2008; Tomas et al. 2009). Accordingly, a considerable number of studies have been published concerning the biology of common dentex in captivity (e.g. Rueda and Martinez 2001; Koumoundouros et al. 2004; Suarez et al. 2009; Rigos et al. 2012). 
Despite its economic and ecological importance, scientific peer-reviewed papers on the biology of this species in its natural environment are still very scant. The most important study described the fishing and biology of Dentex dentex from the Balearic Islands off Mallorca (Morales-Nin and Moranta 1997), and another on its age and growth on the Tunisian coast (Chemmam-Abdelkader 2004; Chemmam-Abdelkader et al. 2004). While specific studies on this species are scarce, there is piecemeal information on it in scientific reports and in peerreviewed papers, regarding its morphology and geographical distribution (Bauchot and Hureau 1986; MoralesNin and Moranta 1997), the range of habitats it occupies (Bayle-Sempere et al. 1991; Ramos-Esplà and BayleSempere 1991), its reproduction and growth (Morales-Nin and Moranta 1997; Chemmam-Abdelkader 2004), parasite communities (Radujkovic and Euzet 1989; Euzet et al. 1993; González et al. 2004; Bartoli et al. 2005), the fishing gear used (Cetinic et al. 2002; Lelli et al. 2006; Sacchi et al. 2010; Sacchi and Dimech 2011), catches and annual production (FAO 2012), regulations and management through marine protected areas (e.g. Francour 1994; Cacaud 2003; Sahyoun et al. 2013), and on its population structure and stock discrimination (Bargelloni et al. 2003; Palma and Andrade 2004; Chemmam-Abdelkader et al. 2007). There is a lack of basic biological studies for several Mediterranean fish populations, and yet this information is most important for the conservation of biodiversity and sustainable fishery management (Tzanatos et al. 2008; Damalas et al. 2010). This review summarizes the current literature on D. dentex biology, ecology, stock structure, and fisheries, and suggests future research directions to fill the gaps in current knowledge.

\section{General description}

The common dentex has a rather short compact oval body (Bauchot 1987). Its head profile is straight in juveniles and convex in adults (Bauchot 1987; Bayle-Sempere et al. 1991). The oldest specimens have a slight hump at their forehead (Bauchot and Hureau 1986). It has several rows of teeth, with 4-6 well-developed anterior teeth on each jaw (Bauchot 1987), and a succession of canine teeth that are much smaller than the frontal ones (BayleSempere et al. 1991). Its gillrakers are present on the first arch, 9 or 10 lower and 8 or 9 upper (Bauchot and Hureau 1986; Bauchot 1987). Its dorsal fin has 11 spines of increasing length up to the fourth or fifth, and subequal thereafter (Bauchot and Hureau 1986). Its ventral fins are characterized by one spine and five radii, the pectoral fins are composed of an average of 15 radii, and the caudal fin present 17 radii (Chemmam-Abdelkader 2004). On the anal fin, there are three spines, and between seven and nine radii (Bayle-Sempere et al. 1991). Its lateral line is composed of 62 to 68 scales to the caudal base (Bauchot and Hureau 1986). Its colour changes with age, the young of the year displaying yellow fins (Louisy 2005) or even appearing entirely yellow (Cheminée, 
2012); older juveniles are greyish with vertical black bars and are blue-spotted, turning pinkish at maturity, with yellow areas on the ventral part of the head, then grey-blue in the oldest specimens. There are also dorsal spots that are variably shaded with age (Bauchot and Hureau 1986; Bauchot 1987), and green, blue, gold and purple iridescence, especially in the head region (Gonzales 2005). For Sparidae in general and in particular Dentex dentex, there are no characters that distinguish between sexes. The common dentex is often confused, especially in fisheries statistical data, with other Sparidae such as the red porgy (Pagrus pagrus), which resembles it in shape and body colour. This precise morphological description of the species can be a reliable tool for its identification, for both biologists and MPA managers.

\section{Distribution and habitat}

Dentex dentex is a Mediterranean and Atlantic species (Bayle-Sempere et al. 1991). It inhabits the Mediterranean Sea most frequently south of $40^{\circ}$, it is found occasionally in the Black Sea, and occurs in the Atlantic Ocean exceptionally around the British Isles, and also Cape Blanc, the Bay of Biscay, Madeira, the Canary Islands and southward to Senegal (Fig.1; Bauchot and Hureau 1986; Morales-Nin and Moranta 1997; Bat et al. 2005). In 2008, small juvenile Dentex dentex were observed in the Arcachon basin (Quero et al. 2009). This observation implies that common dentex may spawn in the Bay of Biscay. It has been reported 12 times in all: five times in the 19th century with large erratic individuals, six times in the 20th and once in the 21 st century also with the presence of juveniles $(<20 \mathrm{~cm})$ in the Basque country (Quero et al. 2009). Dentex dentex is a demersal sparid fish found from 0 to $200 \mathrm{~m}$ depth, living on various substrates such as Posidonia oceanica meadows, rocky bottom with $P$. oceanica patches, coastal detritic areas, ripples of coarse sand, sandy habitats with Caulerpa and Cymodocea and in the coralligenous community (Ramos-Esplà and Bayle-Sempere 1991; Abellán 2000; Guidetti 2000; Rueda and Martinez 2001; Ballesteros 2006; Stobart et al. 2012). Juveniles of common dentex (20-50 mm TL, during June-August) inhabit shallow water (2-4 m depth), at the edge between Posidonia oceanica meadows and sand, or close to crevices and small caves (Dulčić et al. 2002; Valle and Bayle-Sempere 2009). From the perspective of behavioural ecology, the juveniles are gregarious; observations of shoals of Dentex dentex have been made, with individuals of medium size (1-5 $\mathrm{kg}$ ) especially in summer around rocky outcrops at depths between 20 and $50 \mathrm{~m}$, but also found in shallow waters ( -8 to $-10 \mathrm{~m}$ ) (Bauchot and Hureau 1986; Bayle-Sempere et al. 1991; Ramos-Esplà and Bayle-Sempere 1991; Francour 1994; ChemmamAbdelkader 2004; Sahyoun et al. 2013). Behaviour changes with age; the oldest adults animals are solitary (Bauchot and Hureau 1986). 


\section{Feeding and behavioural ecology}

Morales-Nin and Moranta (1997) reported that in the Balearic Islands, the adults feed mainly on fish from the coastal zone (74\%) and on cephalopods (26\%) as secondary prey. The smaller individuals had species from the Posidonia meadow in their stomachs: sparids, clupeids, gadoids, and more frequently labrids such as the peacock wrasse (Symphodus tinca, 22.58\%). In larger specimens, fish were the predominant prey, mainly sparids, picarel and anchovy. Whole cephalopods, remains of sepia bone and unidentified beaks were also found (25.62\%). However, their prey species are diverse, probably depending on availability (Morales-Nin and Moranta 1997). On the Tunisian coast the common dentex feeds preferentially on fish (84\%), crustaceans (9\%), cephalopods (5\%) and plant remains (2\%) (Chemmam-Abdelkader 2004). Pelagic fish (eg Trachurus sp, Sardina pilchardus) constitute the majority of prey (56.1\%), compared with other fish. The group "Crustacea" is composed mainly of the caramota prawn (Penaeus kerathuru), the group "Cephalopods" of the common cuttlefish (Sepia officinalis), and the European squid (Loligo vulgaris), and the group "Plants" of the Posidonia oceanica and Caulerpa genus. The common dentex is a high level tropic predator $(4.5 \mathrm{TL})$, and the large size of the adults probably limits the number of predators (Morales-Nin and Moranta 1997; Stergiou and Karpouzi 2001; Froese and Pauly 2012). However, a study on the food and feeding habits of the amberjack Seriola dumerili (Risso, 1810) indicates that the common dentex, probably at the juvenile stage, may be considered as an occasional prey for this species (Andaloro and Pipitone 1997).

\section{Reproduction}

There is almost no information on the reproductive biology of common dentex in the natural environment.

Based on the macroscopic examination of gonads from 210 fish caught from the waters off Mallorca, they reported an equal sex distribution and a gonochorism for the common dentex (Morales-Nin and Moranta 1997). Seasonal variations in the sex ratio of the common dentex were observed on the Tunisian coasts, with an apparent dominance of females compared with males all year round, and a dominance of males during the spawning period (April-June) (Chemmam-Abdelkader 2004). This dominance of males during the spawning period could be explained by fertilization of eggs of one female by several males (Chemmam-Abdelkader 2004). In addition, macroscopic examination of $D$. dentex gonads throughout its life cycle revealed rare cases of hermaphroditism. In this study 3727 individuals were examined, and only 14 immature individuals (with sizes between 17.5 and $24.8 \mathrm{~cm}$ ) were presented with gonadal parts more developed in females than in males or vice versa. 
The species $D$. dentex can be characterized by a rudimentary nonfunctional hermaphroditism. The reproduction occurs from the end of March until June (Morales-Nin and Moranta 1997). In winter most of the specimens are immature, with the development of the gonads starting in January, the first mature specimens appearing in March. The size at which $50 \%$ of the population is mature is estimated at $34.60 \mathrm{~cm}$ for females and $52.02 \mathrm{~cm}$ for males for the Balearic Islands (Morales-Nin and Moranta 1997), and $23.32 \mathrm{~cm}$ for males, $22.58 \mathrm{~cm}$ for females, for a total of both sexes of $22.95 \mathrm{~cm}$ for the Tunisian coast (Chemmam-Abdelkader 2004). Along the Tunisian coast, at $26 \mathrm{~cm} \mathrm{TL}, 75 \%$ of the population is mature, and at $33 \mathrm{~cm}$ TL $100 \%$ of the population is mature for both sexes (Chemmam-Abdelkader 2004). The maximum maturity occurred in the second quarter of the year, with the first post-spawn specimens appearing in the third quarter (Morales-Nin and Moranta 1997). Examination of the ovaries during the spawning period shows that they have different amounts of oocytes corresponding to different stages of oocyte release (nearly full, half full, almost empty) (Chemmam-Abdelkader 2004). The analysis of the frequency distribution of egg size shows the existence of four modes corresponding to four categories of oocytes issuable at four different periods (Chemmam-Abdelkader 2004). The common dentex is a partial spawner, it emits eggs of the same spawning for several days (Chemmam-Abdelkader 2004). Absolute fecundity of Dentex dentex, on average, is equal to 164,195 eggs per fish, and the average relative fecundity is estimated at 217 eggs per gram of fish (Chemmam-Abdelkader 2004).

Concerning the spawning areas, there is no information reported in the literature, but we collected information in Corsica (France) based on fishermen's knowledge. According to their observations during the spawning period, the populations of common dentex gather periodically on spawning sites at between 40 and $100 \mathrm{~m}$ depth to form shoals. These sites are characterized by hard substrates such as rocky outcrops or wrecks. Most of these sites are identified by fishermen, and each year groups of common dentex come to spawn. Observations made by seine fishers using sonar suggest that the reproductive act occurs mainly during the day, but also at night at full moon. 


\section{Age, growth and condition}

Dentex dentex may reach a maximum length of $100 \mathrm{~cm}$ and a weight of $13 \mathrm{~kg}$ (Ramos-Esplà and Bayle-Sempere 1991; Morales-Nin and Moranta 1997). There are no morphological differences between the two sexes, and the size-weight relationship is similar in both (Morales-Nin and Moranta 1997).

Growth is rapid in the first 2 years of life, $31 \%$ of the maximum length being reached in the first year $(24.1 \mathrm{~cm})$ (Morales-Nin and Moranta 1997). Reported estimates of von Bertalanffy growth parameters are similar among studies (Table 1; Culioli 1986; Morales-Nin and Moranta 1997; Chemmam-Abdelkader et al. 2004).

The fish has the physiological capacity to withstand long periods of fasting, which can actually form part of its life cycle (Vigliano et al. 2002; Navarro and Gutierrez 1995). Several factors, such as seasonal fluctuations, reproduction, including pre-spawning and migration, or availability of prey are responsible for this natural fasting (Pérez-Jiménez et al. 2012). Results suggest that it possesses a high capacity to face this nutritional challenge, given that the reduction in body mass induced by prolonged starvation is far lower than that reported for other sparid fish (Pérez-Jiménez et al. 2012). It is relatively long-lived species, its maximum lifespan exceeding 20 years (Morales-Nin and Moranta 1997), with up to 33 years reported (Chemmam-Abdelkader et al. 2004). It exhibits a low $P / B$ value (0.24; Valls et al. 2012) and a low resilience, with a minimum population doubling time of 4.5-14 years (Froese and Pauly 2012). For these reasons, its populations are considered as slow-recovering (Abdul Malak et al. 2011). However, the calculated values of mortality ( 0.201 for both sexes combined, Morales-Nin and Moranta 1997; 0.24, Valls et al. 2012) indicated a relatively low natural mortality.

Age information forms the basis for calculations of growth rate, mortality rate and productivity, ranking it among the most influential of biological variables (Campana 2001). Several calcified structures produce periodic growth increments useful for age determination in fish (Campana 2001). One of the main problems in ageing is selecting the most suitable and accurate structure (Machias et al. 2002). For common dentex, like for most fish, two main structures are used to determine age: scales and otoliths. The direct method by scale reading has been widely used for ageing because scales are easily collected, prepared and read (Machias et al. 2002). ChemmamAbdelkader et al. (2004) showed in $D$. dentex the presence of a strong positive correlation between scale radius and the standard length of fish. The limitation of this method is that the scales of the common dentex older than five years are illegible owing to the poor definition of the annual rings and the abundance of false rings (Morales-Nin and Moranta 1997). The use of hard structures such as sagittal otoliths is generally the most reliable method for quantifying age and growth in fishes (Zischke 2012). Sagittal otoliths appear to be more reliable than scales for aging dentex, especially for older individuals. The formation of annuli on scales and the 
hyaline or opaque zones on otoliths have been attributed to various factors such as seasonal temperature, wet and dry seasons, fish feeding and reproductive cycles (Simkiss 1973; Beckman and Wilson 1995). The results of Morales-Nin and Moranta (1997), on the common dentex indicate a period of hyaline zone formation in autumnwinter and an opaque zone formation in spring-summer. The formation of the hyaline rings in the otoliths, as in most fishes, is probably related to the decrease in the temperature and reduction in food availability (MoralesNin and Moranta 1997). Apparently, reproduction does not influence the type of ring deposited, since during the period of maximum spawning an opaque ring is formed (Morales-Nin and Moranta 1997).

\section{Parasitology}

Parasites have been widely used as biological tags to provide information for fisheries management on the movements and population discreteness of their fish hosts (Williams et al. 1992). Along with the need to correctly identify a stock before it can be appropriately managed, parasites also need to be correctly identified before they can be applied as biological tags (Catalano et al. 2013). The main factor limiting the use of marine parasites as biological tags is insufficient information on their complex biology and ecology (MacKenzie et al. 2008). Numerous investigations concerning the parasite fauna of several sparid fishes from the Western Mediterranean have been published (e.g. Brian 1906; Yamaguti 1963; Bartoli et al. 1989; Ternengo et al. 2009; Kaouachi et al. 2010; Marzoug et al. 2012). There have been no specific studies on the parasite communities present in the common dentex, but much reported data are nevertheless available. A set of reported parasite species from $D$. dentex is given in Table 2. There are some studies on abundance, intensity, prevalence, and their descriptions for digeneans (Bartoli and Bray 1987; Bartoli et al. 1989; Bartoli et al. 2005; Foata et al. 2012; Greani et al. 2012). For ectoparasites, there are references to the gill parasites, especially copepods (Brian 1906; Raibaut et al. 1998; Bailly 2012), but data on monogeneans are scant (Radujkovic and Euzet 1989; Euzet et al. 1993; González et al. 2004). 


\section{Fisheries}

Fish from the Sparidae family are widely distributed along the coastal waters of the Mediterranean Sea, being considered traditionally as an important resource for small-scale fishing (Coppola 2001). Common dentex are of great economic importance as fished species (Chemmam-Abdelkader et al. 2006).

FAO data on global capture production for the last sixty years for D. dentex (Fig.2) show interannual fluctuations. Time-series analyses show four peaks of production, the first between the years 1950 and 1953 with a maximum production of $5400 \mathrm{~T} / \mathrm{year}$, the second during the years 1962-64 with a production that reached $8700 \mathrm{~T} / \mathrm{year}$, the third between 1976 and 1980 with a production of 4143 T/year and finally between 1990 and 1994 with a production of 10329 T/year.

Assuming that fishing effort did not fluctuate, we note the marked demographic changes experienced by populations every few years. At the national level only two countries contribute significantly to catches of common dentex. The main one is Spain, which alone accounted for almost all the overall common dentex production until 1980, when its production declined until 2010. Considering in detail the catch data for Spain during the years 1950 to 1980 , it appears that most fish were caught in Eastern, Central and Northeast Atlantic regions. These areas are not usually the main areas for common dentex; hence caution is needed in data interpretation. From the years 1965-70 Italian production increased, with peaks and troughs, reaching its highest level in 1992. Production then declined abruptly until 2000, to stabilize at lower levels until 2010. It seems that the rapid increase in the exploitation rate observed during the years 1956-63 in Spain, and 1981-92 in Italy seems to have had the major effect of causing sudden depletion, a scenario already reported for other demersal species (e.g. Hidalgo et al. 2009; Quetglas et al. 2012). These two countries have successively dominated production from 1950 to 2000, although at the national level there is broad heterogeneity of the catches over time. It seems that researchers and artisanal fishermen share the same opinion on the existence of cyclic fluctuations of $D$. dentex populations, giving years without catches of this species (Bayle-Sempere et al. 1991).

The main fishing gear specifically targeting the common dentex is: bottom long-lines, trammel nets and medium-large mesh gillnets (Morales-Nin and Moranta 1997; Lelli et al. 2006; Vandeperre et al. 2006; Sacchi and Dimech 2011). However, it can also be targeted by other fishing gear such as bycatch, especially at the juvenile stage, by traps nets, fyke net, basket traps, bottom-trawl, purse and beach seines, "Tramata" fishing used only in the eastern Adriatic, or "Gangui" fishing used along Mediterranean north coastline (Cetinic et al. 2002; Akyol 2003; Quero et al. 2009; Vandeperre et al. 2006; Sacchi et al. 2010). Trammel nets are gangs of three rectangular nets made up of two outer, large-mesh panels and one inner panel (Goñi et al. 2003). For the 
common dentex fishery, the smaller mesh panel reaches a size of $40 \mathrm{~mm}$ stretched, and large-mesh up to $150 \mathrm{~mm}$ stretched. It is composed of a bottom rope with sinkers, and a head rope equipped with floats (Leleu 2012), to deploy the net vertically (up to $5.8 \mathrm{~m}$ ), with a length of $500 \mathrm{~m} \mathrm{(3-4} \mathrm{units} \mathrm{per} \mathrm{vessels).} \mathrm{In} \mathrm{addition} \mathrm{to} \mathrm{wedging,}$ gilling and entangling (i.e., held by teeth, spines or other protrusions), trammel nets also catch fish in the pocket formed by the inner smaller mesh wall of netting being pushed through one of the larger mesh outer walls (Erzini et al. 2006). It is usually installed in the evening and retrieved at dawn (between 12 and 24 hours). Medium mesh size gillnets are built with a single wall of monofilament net with a stretched mesh size of $48-120 \mathrm{~mm}$, and target medium size fish such as sparids on shallow sandy and mixed sandy rocky bottoms (Lelli et al. 2006). The length of these nets ranges from a few hundred meters to more than $1000 \mathrm{~m}$ (Sacchi and Dimech 2011). Bottom longlines consist of monofilament mainline to monofilament snoods with hooks about $1 \mathrm{~m}$ long, attached at regular intervals (Lelli et al. 2006). The most common gear used is $1.2 \mathrm{~mm}$ diameter mainline with $0.6 \mathrm{~mm}$ snood and hooks of length $3 \mathrm{~cm}$ and width $1.5 \mathrm{~cm}$ (Sacchi and Dimech 2011). The bait is mainly cephalopods and sardines (Sacchi and Dimech 2011). During the same fishing day typical artisanal Mediterranean vessels (generally less than $12 \mathrm{~m}$ in length) can deploy more than one longline unit (2-3 per vessel) of 200-300 hooks each, for a length of about $1 \mathrm{~km}$ of longlines (Lelli et al. 2006). In sum, the common dentex is targeted by artisanal fisheries throughout the year using different gear. We note that there is an alternation and/or combined use of this gear (top three: longline, trammel and gill net), depending on the season, habitat and geographic areas (Table 3). However, for common dentex fishing, peaks of exploitation were observed, with maximum efficiency between May and September by trammel net/gill nets and between September and April by bottom long-line. The fishing depth is mostly in the range $15-80 \mathrm{~m}$, with a mean value around depth $30 \mathrm{~m}$. The composition by size class also shows broad variations in terms of catches $(14-83 \mathrm{~cm})$. Juvenile stages (mean value $30 \mathrm{~cm}$ ) are captured especially on the Posidonia oceanica meadows (by trammel net and gill net) or as by-catch (e.g Tramata, gangui), whereas adult specimens are caught mainly on the rocky bottoms (by long-line).

\section{Recreational fishing}

Recreational fishing has economic, social, and cultural roles in the Mediterranean (Morales-Nin et al. 2005). It has been recognized as one of the most common leisure activities in coastal zones (Albouy et al. 2010). One of the possible definitions that can be given for recreational fishing is: "Fishing activities exploiting marine living aquatic resources from which it is prohibited to sell or trade the catches obtained" (Anonymous 2011). The 
common dentex, due to its large size, flesh quality, and high commercial value, is considered as a "noble" species, and is therefore also targeted by recreational fishing. There are few data regarding fishing effort, total catch from most recreational fishing (Lloret and Font 2013), and fishing for common dentex suffers from similar deficiencies. The most common methods used in recreational fishing for D. dentex are boat fishing, spear fishing, line and shore fishing (Morales-Nin et al. 2005; Lloret et al. 2008; Gordoa 2009; Abdul Malak et al. 2011; Font and Lloret 2011). The angling techniques used generally to catch $D$. dentex are varied; bait can be alive or dead, or artificial lures can be used. Along the coast of the marine reserve of Cap de Creus, live fish such as Serranus cabrilla or Coris julis are used to catch valuable fish such as D. dentex, and represented $9.9 \%$ of the total bait used by shore anglers in 2007 and 2009. For the common dentex, cephalopods (body portions or dead animals) such as squid, cuttlefish, octopus and bobtail squid, constitute $15.5 \%$ of the total baits used, and sardine (Sardina pilchardus) with $13.7 \%$ (Font and Lloret 2011). The results highlight the relatively high mean vulnerability and trophic level of rocky benthic fish species caught by shore fishing and spear fishing; this is mainly due to relatively large catches in terms of weight of top predators such as D. dentex (Lloret et al. 2008; Font and Lloret 2011). Commercial and recreational fishing have similar demographic and ecological effects on fished populations, and they can have equally serious ecological and economic consequences (Cooke and Cowx 2004; Font and Lloret 2011). In some geographic areas the spear fishermen are perceived as the main competitors by artisanal fishing, who become strong market competitors by selling their catches (illegally) to local restaurants at a high price without a commercialization license, therefore affecting demand (Maynou et al. 2013). There is clear evidence that recreational activities not only impact marine resources quantitatively, but in addition modify their structure (Rocklin et al. 2011). In particular, the removal of large individuals can adversely affect the reproductive potential of these vulnerable fish populations (Lloret et al. 2012; Prato et al. 2013).

\section{Regulation and minimum fish sizes}

The common dentex seems to be a heavily exploited species, and it is considered to be threatened in the Mediterranean Sea (Abdul Malak et al. 2011). Considering the effect of the professional fishing exploitation combined with recreational fishing on coastal ecosystems, it seems important to create new regulation policies (Albouy et al. 2010; Lloret and Font 2013) for both these activities. The measures should consider limiting or banning catching through permanent or seasonal closures during the spawning season, the establishment of a minimum legal length (based on species size at maturity) and/or the enlargement of no-take in critical areas (Lloret et al. 2008; Abdul Malak et al. 2011). For recreational fishing (including spear fishing), as stated 
previously, there is a general lack of knowledge on this activity, and it seems urgent, in the light of its impact, particularly on populations of common dentex, to implement effective measures of regulation and control. For commercial fishing, in some Mediterranean countries, there is a regulation imposing a minimum landing size of common dentex (Table 4). Unfortunately, depending on the country, even when there is a minimum landing size, this remains well below the size at which $50 \%$ of the population is mature, namely $34.60 \mathrm{~cm}$ for females and $52.02 \mathrm{~cm}$ for males (Morales-Nin and Moranta, 1997).

\section{Marine protected areas}

There are important differences in the fish assemblages inhabiting protected and unprotected areas (e.g. Macpherson et al. 1997, 2002; Pinnegar et al. 2000; Guidetti and Sala 2007; Garcia-Charton et al. 2008). The impact of protection, or the 'reserve effect', can be observed as a clear increase in abundance, the average and maximum individual sizes of most target species, and changes in the spatial distribution through recovery of shallow water habitats (e.g. Francour et al. 2001; Garcia-Charton et al. 2008). The common dentex is one those that benefits from these protection measures, being especially threatened by recreational and professional selective and effective fishing (Macpherson et al. 2002). However, results indicate that some relatively highmobility species have benefited from habitat protection, whereas less mobile ones have suffered (Gomez et al. 2006). In Port de la Selva (Spain), the proportion of top predators such as $D$. dentex in total landings increased after the establishment of the MPA at the expense of octopus (Octopus vulgaris), white seabream (Diplodus sargus), scorpionfish (Scorpaena sp), and spiny lobster (Palinurus elephas) (Gomez et al. 2006). In the Bonifacio straits (France) the significant decrease in Serranus cabrilla could be linked to the significant increase in D. dentex (Rocklin et al. 2011). In the fishing reserves located in Calvi (France), a rearrangement of the demographic structure of some species was also found, with lower ratios of small species to large (Pelaprat 2000). The explanation for this difference was based on increased predation within the reserve due to a number of larger predators such as D. dentex (Francour et al. 2010; Prato et al. 2013). Such a trend is generally not expected after MPA implementation, but can be explained by trophic interactions between species through a topdown effect, where an increase in predators would lead to a decrease in their prey (Pinnegar et al. 2000; Pinnegar and Polunin 2004; Seytre and Francour 2009). 


\section{Stock structure and assessment}

An important first step toward assessing the sustainability of an exploited population is to define the geographic boundaries, or stock units, for the species (Quinn II and Deriso 1999). Unfortunately, little is known of the global stock structure and movement of $D$. dentex.

There is only one study on the population genetics of $D$. dentex at the global level. This study describes the phylogeography of three sparids including $D$. dentex based on three geographic areas: the Northeast Atlantic, and the Western and Eastern Mediterranean Sea (Bargelloni et al. 2003). For the D. dentex, mitochondrial DNA and allozymes have revealed a higher degree of genetic differentiation between the Atlantic and Mediterranean samples. Morphometric measurements were performed on these same samples of D. dentex (Palma and Andrade 2004). A significant degree of morphological dissimilarity between samples, and a geographical gradient were found (Palma and Andrade 2004). These results based on genetic and morphological analysis are evidence for a sharp phylogeographic break between the Atlantic and the Mediterranean for populations of common dentex (Bargelloni et al. 2003; Palma and Andrade 2004). Reported differences in fish size and growth may be due to fishing pressure, changes in oceanographic conditions, food availability, and season (Shelton and Mangel 2011). There seems to be an effective boundary between the Atlantic and Mediterranean populations of dentex, both morphologically and genetically (Bargelloni et al. 2003; Palma and Andrade 2004). It can be hypothesized that the history of the Mediterranean Sea, combined with the present hydrographic patterns, may have promoted and maintained the differentiation of the Mediterranean samples (Bargelloni et al. 2003; Palma and Andrade 2004). However, there is a severe lack of information on population structure, and it would require further studies including a higher spatial resolution and more accurate molecular markers (e.g. microsatellites).

To date, the only studies on the stock assessment of common dentex were conducted in Tunisia; three stocks were separately addressed according to different regions: Northern, Eastern and South (Chemmam-Abdelkader 2004; FAO 2008). These are the first studies on the analysis of the pseudo-cohort of this species in the Mediterranean, which yielded the main components of the stock in Tunisia. In the North, the yield by recruit value was below the optimal level; the stock seems to be under-exploited. The exploitation profile in the Eastern region was in optimal conditions. By contrast, the stock of the southern region is strongly overexploited, with a current yield above the optimum performance (Chemmam-Abdelkader 2004). The results obtained in the South Tunisian sector show that fishing is carried out on small size classes composed mainly of juveniles (ChemmamAbdelkader et al. 2007). The current average age of the stock is estimated at 1.9 year, and is very low if we consider the longevity of the species, which can be more than 30 years. The effort to ensure stock replenishment 
or "turnover" was $48 \%$. For losses, the fishing mortality (63\%) outweighed the natural mortality, probably because of overfishing. The profile of Southern stock was characterized by a young average age, a critical size close to that of sexual maturity, reflecting a state of overfished stock. To remedy this, the reduction of the current fishing effort by $44 \%$ compared with the optimal effort is recommended (Chemmam-Abdelkader et al. 2007). The recommendations include as a precautionary measure not increasing the fishing effort in both areas (FAO 2008). At a global level, efforts are to be made on the stock assessment of the common dentex, to better understand its movement and how the individuals comprising the various $D$. dentex aggregations in different localities are related.

\section{Conclusion and directions for future research}

Here we have shown that although the common dentex species is of great interest, both economically and ecologically, some very important questions still remain unanswered about the life of this iconic fish.

As a top predator, it is a key species in the functioning of coastal food webs, and for this reason there is a need to improve the state of knowledge on the biology and ecology of the common dentex. In order to implement proper fishery management strategies aimed at avoiding stock decline, information about connectivity among stocks and populations is critical. There is still great progress to be made in understanding the larval and juvenile stages and the reproductive behavior of the common dentex. There should also be a clear vision of the population state (demographic parameters) and the spatial and temporal structure of the stocks, to implement sustainable management of fisheries in the Mediterranean Sea. Consequently, more specific methods may be more helpful in defining stock boundaries for population models. Genetic techniques using specific microsatellite loci may provide a more comprehensive analysis of the genetic population structure of the common dentex (Bargelloni et al. 2003). Some other specific approaches could be relevant in determining the stock structure of the common dentex, such as parasite abundances (e.g. Williams et al. 1992; MacKenzie and Abaunza 1998; Williams and Lester 2006), stable isotope analysis (e.g. Rooker et al. 2007) and otolith shape and/or microchemistry (e.g. Turan 2006; Hamer et al. 2012). From the perspective of behavioral ecology, one path of research that can be developed is to investigate the movement of individuals, for example using electronic tagging, especially for aggregations at the time of reproduction (e.g. Pastor et al. 2009). However, the development of simultaneous multiple approaches such as analysis of fisheries data, population genetics, and otolith chemistry is probably the most relevant way to favour the efficient management of an exploited species (see Pappeti et al. 2013). 
In terms of exploitation, for recreational fishing, it is necessary to have short-term, accurate biological, social and economic data to evaluate this activity (Pitcher and Hollingworth 2002; Arlinghaus et al. 2010). Recreational catches are often poorly quantified, but such catch data are essential for estimating total mortality in stock assessment, especially where the recreational catch is high compared with the commercial catch (Lloret and Font 2013). Despite its importance, knowledge about fleets and their characteristics, fishing gear, seasonality, catches, and the yields of the professional artisanal sector is still limited (Battaglia et al. 2010). It is necessary to develop standardized data collection routines and indicators of fishing effort for Mediterranean artisanal fishery that make data comparable on a spatial and temporal basis (Colloca et al. 2004). Data on global catch of common dentex suggests a cyclic fluctuation of the populations, with the appearance of multiannual peaks of activity. The abundance of common dentex has fluctuated over the last sixty years on a multidecadal time scale and has declined significantly since the 1990s. In some areas, populations have decreased significantly in recent years, due to overfishing by artisanal and recreational fishing. Fishing gear such as trawl or seine may make a particular impact on these populations, especially in spawning areas (mature adults) or nursery areas such as in the Posidonia oceanica meadows (juveniles and young of the year). However, the interaction between fishing exploitation and environmental variables can have synchronic effects on the population dynamics of exploited marine fishes (Quetglas et al. 2012). The improved management of fisheries and marine ecosystems can undoubtedly play an important role in adapting to the impacts of climate change (Brander 2010). Managers should consider the implementation of specific measures to safeguard the reproductive potential of coastal top predator species, such as D. dentex (Lloret et al. 2012). There is an urgent need to implement effective protection measures for this species, whether based on a maximum daily catch, minimum catch size, protection through marine protected areas, or period of biological recovery, because recently $D$. dentex has been classified as "vulnerable" in the Red List of Threatened Species in the Mediterranean Sea and so effective management is now required.

\section{Acknowledgements}

This research was partially supported by the "Fonds Européen de Développement Régional" (FEDER), the “Collectivité Territorial de Corse" (CTC) and the "Università di Corsica Pasquale Paoli (UCPP). We thank, Prof. Antoine Aiello, Jean-Michel Culioli, Dr Henri Farrugio, Dr Pierre Lejeune and Dr Dominique Ponton for valuable discussions on the common dentex. Special thanks are extended to the fishermen of the Island of Corsica for their collaboration through their observations. 


\section{$\underline{\text { References }}$}

Abdelkader B, Ktari MH ( 1986) Régime alimentaire des Dentés (genre Dentex), Poissons, Sparidés de Tunisie. Tunisie. Bull Soc Sc Nat 17:19-25

Abdul Malak D, Livingstone SR, Pollard D, Polidoro BA, Cuttelod A, Bariche M, Bilecenoglu M, Carpenter KE, Collette BB, Francour P, Goren M, Kara MH, Massutí E, Papaconstantinou C, Tunesi L (2011) Overview of the Conservation Status of the Marine Fishes of the Mediterranean Sea. Gland,Switzerland and Malaga, Spain: IUCN.61

Abellán E (2000) Culture of common dentex (Dentex dentex L.). Present knowledge, problems and perspectives. Cah Options Mediterr 47:157-168

Akyol O (2003) Retained and trash fish catches of beach-seining in the Aegean coast of Turkey. Turk J Vet Anim Sci 27: 1111-1117

Albouy C, Mouillot D, Rocklin D, Culioli JM, Le Loc'h F (2010) Simulation of the combined effects of artisanal and recreational fisheries on a Mediterranean MPA ecosystem using a trophic model. Mar. Ecol. Prog. Ser. 412:207-221. doi:10.3354/meps08679

Andaloro F, Pipitone C (1997) Food and feeding habits of the amberjack, Seriola dumerili in the Central Mediterranean Sea during the spawning season. Cah Biol Mar 38 (2):91-96

Anonymous (2011) Report of the Transversal Workshop on the Monitoring of Recreational Fisheries in the GFCM Area. GFCM, Palma de Mallorca, Spain.

Arceo HO (2012) Assessing the effectiveness of marine protected areas in sustaining small-scale fisheries : ecological and management perspectives from the French Mediterranean. Université Nice Sophia Antipolis, Nice.

Arculeo M, Lo Brutto S, Sirna-Terranova M, Maggio T, Cannizzaro L, Parrinello N (2003) The stock genetic structure of two Sparidae species, Diplodus vulgaris and Lithognathus mormyrus, in the Mediterranean Sea. Fish Res 63 (3):339-347

Arlinghaus R, Cooke S, Cowx I (2010) Providing context to the global code of practice for recreational fisheries. Fish Manag Ecol 17:146-156

Bailly N (2012) Dentex dentex (Linnaeus, 1758). In: Froese R, Pauly D Editors (2012) FishBase Accessed through: World Register of Marine Species at http://wwwmarinespeciesorg/aphiaphp?p=taxdetails\&id=273962 on 2012-10-25

Ballesteros E (2006) Mediterranean coralligenous assemblages: a synthesis of present knowledge. Oceanogr Mar Biol Annu Rev 44:123-195

Bargelloni L, Alarcon JA, Alvarez MC, Penzo E, Magoulas A, Reis C, Patarnello T (2003) Discord in the family Sparidae (Teleostei): divergent phylogeographical patterns across the AtlanticMediterranean divide. J Evol Biol 16 (6):1149-1158. doi:10.1046/j.1420-9101.2003.00620.x

Bartoli P, Bray R (1987) Redescriptions of two cryptogonimid digeneans from the fish Dentex dentex (L., 1758) (Sparidae) in the Mediterranean Sea. Syst Parasitol 10 (2):117-127. doi:10.1007/bf00009617

Bartoli P, Bray R, Gibson D (1989) The Opecoelidae (Digenea) of sparid fishes of the western Mediterranean. III. Macvicaria Gibson \& Bray, 1982. Syst Parasitol 13 (3):167-192. doi:10.1007/bf00009743

Bartoli P, Gibson DI, Bray RA (2005) Digenean species diversity in teleost fish from a nature reserve off Corsica, France (Western Mediterranean), and a comparison with other Mediterranean regions. J Nat Hist 39 (1):47-70. doi:10.1080/00222930310001613557

Bat L, Erdem Y, Ustaoglu S, Yardim Ö, Hüseyin Satilmis H (2005) A study on the fishes of the Central Black Sea coast of Turkey. J Black Sea/Mediterranean Environment 11:291-296

Batista MI, Teixeira CM, Cabral HN (2009) Catches of target species and bycatches of an artisanal fishery: The case study of a trammel net fishery in the Portuguese coast. Fish Res 100 (2):167-177. doi:http://dx.doi.org/10.1016/j.fishres.2009.07.007 
Battaglia P, Romeo T, Consoli P, Scotti G, Andaloro F (2010) Characterization of the artisanal fishery and its socio-economic aspects in the central Mediterranean Sea (Aeolian Islands, Italy). Fish Res 102 (102):87-97

Bauchot M-L (1987) Fiches FAO d'identification pour les besoins de la pêche. (rev. 1). Méditerranée et mer Noire. Zone de pêche 37. Poissons osseux In W Fischer, ML Bauchot and M Schneider (eds) 2:891-1421

Bauchot ML, Hureau JC (1986) Fishes of the North-Eastern Atlantic and the Mediterranean. Sparidae In Whitehead, PJP, Bauchot, ML, Hureau, JC, Nisen, J and Tortonese, E(Eds) UNESCO, Paris 2, 883-907

Bauchot M-L, Hureau J-C (1990) Check-list of the fishes of the eastern tropical Atlantic (CLOFETA). Sparidae In: JC Quero, JC Hureau, C Karrer, A Post and L Saldanha JNICT-Portugal, SEI-France, Unesco Vol. II:790-812

Bayle-Sempere JT, Ramos-Espla AA, Mas Hernandez J (1991) Observations on Dentex dentex (L., 1758 ) in the Spanish Mediterranean. In: CF Boudouresque, M Avon and V Gravez (Editors) Les Espèces Marines à Protéger en Méditerranée GIS Posidonie Publ, Fr, 245-253

Beckman DW, Wilson CA (1995) Seasonal timing of opaque zone formation in fish otoliths. In Secor, DH, Dean, JM, Campana, SE, Miller, AB (Eds) Recent Developments in Fish Otolith Research University of South Carolina Press, Columbia, SC:27-41

Bodilis P, Clozza M, Francour P (2012) Suivi des biocénoses et des peuplements de poissons de 4 sites non protégés du littoral varois. ECOMERS publ.,Nice

Brander K (2010) Impacts of climate change on fisheries. J Marine Syst 79 (3-4):389-402. doi:http://dx.doi.org/10.1016/j.jmarsys.2008.12.015

Brian A (1906) Copepodi Parasiti dei Pesci d'Italia. Tipo-Litografico R Istituto Sordomuti, Stab, Genova:1-190

Cacaud $\mathrm{P}$ (2002) Revue de la réglementation relative à la pêche maritime et aux aires protégées dans les pays participants au projet Copemed. Rome

Cacaud P (2003) Analyse légale des mesures adoptées par les états côtiers méditerranéens en vue de minimiser l'impact des activités de pêches sur les écosystèmes marins et les espèces non cibles. Projet pour la préparation d'un Plan d'Action Stratégique pour la Conservation de la Biodiversité dans la Région Méditerranéenne (PAS - BIO).

Cadiou G, Bonhomme P (2006) Suivi de l'effort de pêche professionnelle dans les eaux du parc national de Port-Cros. Année 2005. Parc National de Port-Cros \& GIS Posidonie.

Cadiou G, Boudouresque CF, Bonhomme P, Le Diréach L (2009) The management of artisanal fishing within the Marine Protected Area of the Port-Cros National Park (northwest Mediterranean Sea): a success story? ICES J Mar Sci 66 (1):41-49. doi:10.1093/icesjms/fsn188

Campana SE (2001) Accuracy, precision and quality control in age determination, including a review of the use and abuse of age validation methods. J Fish Biol 59 (2):197-242. doi:10.1111/j.1095-8649.2001.tb00127.x

Carreras-Aubets M, Montero F, Kostadinova A, Gibson D, Carrassón M (2012) Redescriptions of two frequently recorded but poorly known hemiurid digeneans, Lecithochirium musculus (Looss, 1907) (Lecithochiriinae) and Ectenurus lepidus Looss, 1907 (Dinurinae), based on material from the western Mediterranean. Syst Parasitol 82 (3):185-199. doi:10.1007/s11230-0129357-8

Catalano SR, Whittington ID, Donnellan SC, Gillanders BM (2013) Parasites as biological tags to assess host population structure: Guidelines, recent genetic advances and comments on a holistic approach. International Journal for Parasitology: Parasites and Wildlife (0). doi:http://dx.doi.org/10.1016/j.ijppaw.2013.11.001

Cetinic P, Soldo A, Dulcic J, Pallaoro A (2002) Specific method of fishing for Sparidae species in the eastern Adriatic. Fish Res 55 (103):131-139 
Cheminée A (2012) Ecological functions, transformations and management of infralittoral rocky habitats from the North-western Mediterranean: the case of fish (Teleostei) nursery habitats., University of Nice, Nice

Chemmam-Abdelkader B (2004) Les Dentés (poissons Sparidés) des côtes tunisiennes: Étude écobiologique et dynamique des populations. Université de Tunis el Manar, Tunis

Chemmam-Abdelkader B, Ezzeddine-Najaî S, Kraiem MM (2007) Etude de l'état du stock de Dentex dentex (Linnaeus, 1758) (Teleostei, Sparidae) des côtes sud tunisiennes. Bull Inst Natn Scien Tech Tabarka 12:55-59

Chemmam-Abdelkader B, Kraiem MM, El Abed A (2004) Etude de l'âge et de la croissance de deux espèces de dentés (Dentex dentex et de Dentex maroccanus) des côtes Tunisiennes. Bull Inst Natn Scien Tech Mer de Salammbô 31:43-51

Chemmam-Abdelkader B, Kraïem MM, Ezzeddine-Najai S (2006) Révision qualitative et quantitative des captures des poissons du genre Dentex (Teleostei, Sparidae) sur les côtes tunisiennes. Actes du 6ème Congrès Maghrébin des Sciences de la Mer (Monastir, Tunisie, 18-22 décembre 2005) Bull Inst Natn Scien Tech Mer Salammbô 10:64-67

Colloca F, Crespi V, Cerasi S, Coppola SR (2004) Structure and evolution of the artisanal fishery in a southern Italian coastal area. Fish Res 69 (3):359-369. doi:http://dx.doi.org/10.1016/j.fishres.2004.06.014

Condal F, Aguzzi J, Sardà F, Nogueras M, Cadena J, Costa C, Del Río J, Mànuel A (2012) Seasonal rhythm in a Mediterranean coastal fish community as monitored by a cabled observatory. Mar Biol 159 (12):2809-2817. doi:10.1007/s00227-012-2041-3

Cooke SJ, Cowx IG (2004) The Role of Recreational Fishing in Global Fish Crises. BioScience 54 (9):857859. doi:10.1641/0006-3568(2004)054[0857:trorfi]2.0.co;2

Coppola SR (2001) Inventory of artisanal fishery communities in the western-central Mediterranean. FAO-COPEMED Project. Working Draft. FAO, publ., Rome : 1- 64

Culioli MJ (1986) Valorisation des ressources de la pêche cotière Corse: Estimation de la production en région de Calvi, étude des paramètres de croissance de cinq espèces de poissons d'intérêt économique. Mémoire de Maîtrise, Université de Corse Pascal Paoli

Culioli J-M (1995) La pêche professionnelle dans la réserve naturelle des lles Lavezzi (Corse): Effort et productions (août 1992-juillet 1993). Travaux scientifiques du Parc naturel régional et des réserves naturelles de Corse.

Damalas D, Maravelias CD, Katsanevakis S, Karageorgis AP, Papaconstantinou C (2010) Seasonal abundance of non-commercial demersal fish in the eastern Mediterranean Sea in relation to hydrographic and sediment characteristics. Estuar Coast Shelf S 89 (1):107-118. doi:http://dx.doi.org/10.1016/j.ecss.2010.06.002

Dulčić J, Matić S, Kraljević M (2002) Shallow coves as nurseries for non-resident fish: a case study in the eastern middle Adriatic. J Mar Biol Assoc Uk 82: 991-993

Erzini K, Gonçalves JMS, Bentes L, Moutopoulos DK, Casal JAH, Soriguer MC, Puente E, Errazkin LA, Stergiou KI (2006) Size selectivity of trammel nets in southern European small-scale fisheries. Fish Res 79 (1-2):183-201. doi:http://dx.doi.org/10.1016/i.fishres.2006.03.004

Esparza-Alaminos Ó (2010) Estudio de la pesca artesanal en el entorno de la reserva marina de Cabo de Palos-Islas Hormigas: estrategias, efecto de la protección y propuestas para la gestión. Universidad de Murcia, Murcia.

Euzet L, Combes C, Caro A (1993) A checklist of Monogenea of Mediterranean fish. Second International Symposium on Monogenea. Montpellier/Sète 5-8 July 1993

FAO (2008) Report of the tenth session of the Scientific Advisory Committee.General Fisheries Commission for the Mediterranean (GFCM). Nicosia, Cyprus, 22-26 October 2007.FAO Fisheries Report No. 856. Rome, FAO. 1-144

FAO (2012) A world overview of species of interest to fisheries. Dentex dentex. FIGIS Species Fact Sheets. Text by Domenec Lloris Species Identification and Data Programme. In: FAO Fisheries and Aquaculture Department [online] Rome Updated 2002 [Cited 31 October 2012] http://www.fao.org/fishery/figis/en 
FAO (2012) FISHSTAT J : FAO Fishery and Aquaculture Global Statistics. FAO Fisheries Department, Fishery Information, Data and Statistics Unit

Foata J, Quilichini Y, Greani S, Marchand B (2012) Sperm ultrastructure of the digenean Aphallus tubarium (Rudolphi, 1819) Poche, 1926 (Platyhelminthes, Cryptogonimidae) intestinal parasite of Dentex dentex (Pisces, Teleostei). Tissue Cell 44 (1):15-21

Font T, Lloret J (2011) Biological implications of recreational shore angling and harvest in a marine reserve: the case of Cape Creus. Aquat Conserv: Mar Freshwat Ecosyst 21 (2):210-217. doi:10.1002/aqc.1167

Forcada A, Bayle-Sempere JT, Valle C, Sánchez-Jerez P (2008) Habitat continuity effects on gradients of fish biomass across marine protected area boundaries. Marine Environmental Research 66 (5):536-547. doi:http://dx.doi.org/10.1016/j.marenvres.2008.08.003

Francour P (1991) The effect of protection level on a coastal fish community at Scandola, Corsica. Revue d'écologie 46 (1):65-81

Francour P (1992) Le peuplement ichtyologique de l'îlot de la Gabinière (Parc National de Port-Cros, Méditerranée nord-occidentale). Parc national de Port-Cros/GIS Posidonie.

Francour P (1994) Pluriannual analysis of the reserve effect on ichtyofauna in the Scandola natural reserve (Corsica, northwestern Mediterranean). Oceanol Acta 17(3): 309-317

Francour P, Boudouresque CF, Harmelin JG, Harmelin-Vivien M, Quignard JP (1994) Are the Mediterranean waters becoming warmer? Information from biological indicators. Mar Pollut Bull 28 (9):523-526

Francour P, Harmelin J-G, Pollard D, Sartoretto S (2001) A review of marine protected areas in the northwestern Mediterranean region: siting, usage, zonation and management. Aquatic Conservation: Mar Pollut Bull 11 (3):155-188. doi:10.1002/aqc.442

Francour P (2004) Etude des peuplements de poissons des zones rocheuses de la réserve naturelle de Scandola : évolution en 10 ans. LEML, publ., Nice.

Francour P (2007) Evolution pluriannuelle de la faune ichtyologique des substrats rocheux et de I'herbier à Posidonia oceanica du parc national de Port-Cros (Var, Méditerranée nordoccidentale) :analyse de la période 1988-2006. Parc national de Port-Cros \& Laboratoire Environnement marin littoral, Nice.

Francour P, Mangialajo L, Pastor J (2010) Mediterranean marine protected areas and non-indigenous fish spreading. in: Fish Invasions of the Mediterranean Sea: Change and renewal. D. Golani \& B. Appelbaum-Golani eds., Pensoft Publisher, Sofia-Moscow: 127-144.

Froese R, Pauly D Editors (2012) FishBase Accessed 10/10/12 World Wide Web electronic publication, www.fishbase.org.

García-Charton JA, Pérez-Ruzafa Á, Sánchez-Jerez P, Bayle-Sempere JT, Reñones O, Moreno D (2004) Multi-scale spatial heterogeneity, habitat structure, and the effect of marine reserves on Western Mediterranean rocky reef fish assemblages. Mar Biol 144 (1):161-182. doi:10.1007/s00227-003-1170-0

Garcia-Charton JA, Pérez-Ruzafa A, Marcos C, Claudet J, Badalamenti F, Bennedetti-Cecchi L, Falcon J M, Milazzo M, Schembri P, Stobart B, Vandeperre F, Brito A, Chemello R, Dimech M, Domenici P, Guala I, Le Direac'h L, Maggi E, Planes S (2008) Effectiveness of European Atlanto-Mediterranean MPAs: Do they accomplish the expected effects on populations, communities and ecosystems? J Nat Conserv 16(2): 193-221.

Garrido M (2007) Etude de l'impact de l'activité de la pêche artisanale et de l'effet de gestion sur les populations d'Epinephelus marginatus (Lowe 1834) dans le périmètre de la Réserve Naturelle des Bouches de Bonifacio. Mémoire de Master,Université de Corse Pascal Paoli.

Giménez G, Estévez A (2008) Effects of two culturing techniques on the growth, survival and larval quality of Dentex dentex Linnaeus, 1758. Aquac Res 39 (4):354-361. doi:10.1111/j.13652109.2007.01726.x 
Gomez S, Lloret J, Demestre M, Riera V (2006) The Decline of the Artisanal Fisheries in Mediterranean Coastal Areas: The Case of Cap de Creus (Cape Creus). Coast Manage 34 (2):217-232. doi:10.1080/08920750500531389

Goñi R, Quetglas A, Reñones O (2003) Differential catchability of male and female European spiny lobster Palinurus elephas (Fabricius, 1787) in traps and trammelnets. Fish Res 65 (1-3):295307. doi:http://dx.doi.org/10.1016/i.fishres.2003.09.021

Gonzales P (2005) Parasitofauna branquial de Dentex dentex (Linneo, 1758) (Pisces; Sparidae). Thesis, Universitat de Valencia, Valencia

González P, Sánchez MI, Chirivella J, Carbonell E, Riera F, Grau A (2004) A preliminary study on gill metazoan parasites of Dentex dentex (Pisces: Sparidae) from the western Mediterranean Sea (Balearic Islands). J Appl Ichthyol 20 (4):276-281. doi:10.1111/j.1439-0426.2004.00548.x

Gordoa A (2009) Characterization of the infralittoral system along the north-east Spanish coast based on sport shore-based fishing tournament catches. Estuar Coast Shelf S 82: 41-49

Greani S, Quilichini Y, Foata J, Marchand B (2012) Ultrastructural Study of Vitellogenesis of Aphallus tubarium (Rudolphi, 1819) Poche, 1926 (Digenea: Cryptogonimidae), An Intestinal Parasite of Dentex dentex (Pisces: Teleostei). J Parasitol 98 (5):938-943. doi:10.1645/ge-3123.1

Guidetti P (2000) Differences among fish assemblages associated with nearshore Posidonia oceanica seagrass beds, rocky-algal reefs and unvegetated sand habitats in the Adriatic sea. Estuar Coast Shelf S 50: 515-529

Guidetti P, Sala E (2007) Community-wide effects of marine reserves in the Mediterranean Sea. Mar Ecol Prog Ser 335: 43-56

Hamer PA, Kemp J, Robertson S, Hindell JS (2012) Multiple otolith techniques aid stock discrimination of a broadly distributed deepwater fishery species, blue grenadier, Macruronus novaezelandiae. FishRes 113 (1):21-34. doi:http://dx.doi.org/10.1016/j.fishres.2011.08.016

Hidalgo M, Tomas J, Moranta J, Morales-Nin B (2009) Intra-annual recruitment events of a shelf species around an island system in the NW Mediterranean. Estuar Coast Shelf S 83 (2):227238. doi:http://dx.doi.org/10.1016/j.ecss.2009.03.037

Jousson O, Bartoli P (2001) Molecules, morphology and morphometrics of Cainocreadium labracis and Cainocreadium dentecis n. sp. (Digenea: Opecoelidae) parasitic in marine fishes. Int J Parasitol 31 (7):706-714

Kaouachi N, Boualleg C, Bensouilah M, Marchand B (2010) Monogenean parasites in Sparid fish (Pagellus genus) in eastern Algeria coastline. Afr J Microbiol Res 4 (10):989-993

Kebapçioglu T, Özgür E, Çardak M, Gökoglu M, Begburs CR (2010) The status of the demersal fish community in the Gulf of Antalya, Turkey (Levantine sea). Rapport de la Commission Internationale pour l'Exploration Scientifique de la Mer Méditerranée, vol 39.

Koumoundouros G, Carrillo J, Divanach P, Kentouri M (2004) The rearing of common dentex Dentex dentex (L.) During the hatchery and on-growing phases. Aquaculture 240 (1-4):165-173. doi:http://dx.doi.org/10.1016/j.aquaculture.2004.01.038

Leleu K (2012) Suivi et évaluation de la pêche professionnelle au sein d'une Aire Marine Protégée: protocoles d'enquêtes et indicateurs de pression et d'impact. Application au Parc Marin de la Côte Bleue. Université Aix Marseille, Marseille.

Lelli S, Carpentieri P, Colloca F, Moubayed S (2006) Commercial landing and fishing metiers within the artisanal fishery of Tyre, Lebanon. In Socio-economic development of the Fishing Community of Tyre, Lebanon' promoted by the Italian NGO 'Ricerca e Cooperazione' in collaboration with Caritas Lebanon and co-financed by the Italian Ministry of Foreign Affairs:1-14

Leroy Y (2009) Influences des caractristiques planctoniques et hydrologiques sur la pêche professionnelle au Cros de Cagnes (Méditerranée occidentale). Université de Liège.

Lloret J, Font T (2013) A comparative analysis between recreational and artisanal fisheries in a Mediterranean coastal area. Fish Manag Ecol in press: doi: 10.1111/j.13652400.2012.00868.x 
Lloret J, Munoz M, Casadevall M (2012) Threats posed by artisanal fisheries to the reproduction of coastal fish species in a Mediterranean marine protected area. Estuar Coast Shelf S 113 (0):133-140. doi:http://dx.doi.org/10.1016/j.ecss.2012.07.015

Lloret J, Zaragoza N, Caballero D, Font T, Casadevall M, Riera V (2008) Spearfishing pressure on fish communities in rocky coastal habitats in a Mediterranean marine protected area. Fish Res 94 (1):84-91

Loir M, Le Gac F, Somarakis S, Pavlidis M (2001) Sexuality and gonadal cycle of the common dentex (Dentex dentex) in intensive culture. Aquaculture 194 (304):363-381

Louisy P (2005) Guide d'identification des poissons marins. Europe et Méditerranée. Ulmer publ., Paris : $1-430$

Machias A, Maraveyia E, Pavlidis M, Somarakis S, Divanach P (2002) Validation of annuli on scales and otoliths of common dentex (Dentex dentex). Fish Res 54 (2):287-294

MacKenzie K, Abaunza P (1998) Parasites as biological tags for stock discrimination of marine fish: a guide to procedures and methods. Fish Res 38 (1):45-56. doi:http://dx.doi.org/10.1016/S0165-7836(98)00116-7

MacKenzie K, Campbell N, Mattiucci S, Ramos P, Pinto AL, Abaunza P (2008) Parasites as biological tags for stock identification of Atlantic horse mackerel Trachurus trachurus L. Fish Res 89 (2):136-145. doi:http://dx.doi.org/10.1016/j.fishres.2007.09.031

Macpherson E, Biagi F, Francour P, García-Rubies A, Harmelin J, Harmelin-Vivien J, Jouvenel JY, Macpherson E, Planes S, Tunesi L, Vigliola L (1997) Mortality of juvenile fishes of the genus Diplodus in protected and unprotected areas in the western Mediterranean Sea. Mar Ecol Prog Ser 147:135-147

Macpherson E, Gordoa A, Garcia-Rubies A (2002) Biomass size spectra in littoral fishes in protected and unprotected areas in the NW Mediterranean. Estuar Coast Shelf S 55: 777-788

Martín JI, Kekez L (2009) Fisheries in Croatia. Directorate General Internal Policies of the Union Policy Department B: Structural and Cohesion Policies. Vol IP/B/PECH/NT/2008_09. European Parliament, Bruxelles

Marzoug D, Boutiba Z, Kostadinova A, Pérez-del-Olmo A (2012) Effects of fishing on parasitism in a sparid fish: Contrasts between two areas of the Western Mediterranean. Parasitol Int 61 (3):414-420

Massuti E, Monserrat S, Oliver P, Moranta J, Lopez-Jurado JL, Marcos M, Hidalgo M, Guijarro B, Carbonell A, Pereda P (2008) The influence of oceanographic scenarios on the population dynamics of demersal resources in the western Mediterranean: Hypothesis for hake and red shrimp off Balearic Islands. J Marine Syst 71 (304):421-438.

doi:http://dx.doi.org/10.1016/j.jmarsys.2007.01.009

Matić-Skoko S, Stagličić N, Pallaoro A, Kraljević M, Dulčić J, Tutman P, Dragičević B (2011)

Effectiveness of conventional management in Mediterranean type artisanal fisheries.

Estuarine, Coastal and Shelf Science 91 (2):314-324.

doi:http://dx.doi.org/10.1016/i.ecss.2010.10.029

Maiorano P, Sion L, Carlucci R, Capezzuto F, Giove A, Costantino G, Panza M, D'Onghia G, Tursi A (2010) The demersal faunal assemblage of the north-western lonian Sea (central Mediterranean): current knowledge and perspectives. Chemistry and Ecology 26 (S1):219240

Maynou F, Morales-Nin B, Cabanellas-Reboredo M, Palmer M, Garcia E, Grau AM (2013) Small-scale fishery in the Balearic Islands (W Mediterranean): A socio-economic approach. Fish Res 139 (0):11-17. doi:http://dx.doi.org/10.1016/j.fishres.2012.11.006

Moutopoulos DK, Ramfos A, Mouka A, Katselis G (2013) LengthWeight Relations of 34 Fish Species Caught by Small-Scale Fishery in Korinthiakos Gulf (Central Greece). Acta Ichthyologica Et Piscatoria 43 (1):57-64. doi:10.3750/aip2013.43.1.08 
Morales-Nin B, Moranta J (1997) Life history and fishery of the common dentex (Dentex dentex) in Mallorca (Balearic Islands, western Mediterranean). Fish Res 30 (1):67-76

Morales-Nin B, Moranta J, Garcia C, Tugores MP, Grau AM, Riera F, Cerda M (2005) The recreational fishery off Majorca Island (western Mediterranean): some implications for coastal resource management. ICES J Mar Sci 62 (4):727-739. doi:10.1016/j.icesjms.2005.01.022

Navarro I, Gutierrez J (1995) Fasting and starvation. Biochemistry and molecular biology of fishes 4:393-434

Orozco M, Lizaso JLS, Fernández A (2011) Capturas del dentón (Dentex dentex) en dos puertos del mediterráneo ibérico. Mediterránea: serie de estudios biológicos (22):212-229

Ottersen G, Kim S, Huse G, Polovina JJ, Stenseth NC (2010) Major pathways by which climate may force marine fish populations. J Marine Syst 79 (3-4):343-360. doi:http://dx.doi.org/10.1016/j.jmarsys.2008.12.013

Palma J, Andrade JP (2004) Morphological study of Pagrus pagrus, Pagellus bogaraveo, and Dentex dentex (Sparidae) in the eastern Atlantic and the Mediterranean Sea. J Mar Biol Assoc UK 84 (02):449-454. doi:doi:10.1017/S0025315404009439h

Papetti C, Di Franco A, Zane L, Guidetti P, De Simone V, Spizzotin M, Zorica B, Kec VC, Mazzoldi C (2013) Single population and common natal origin for Adriatic Scomber scombrus stocks: evidence from an integrated approach. ICES J Mar Sci 70(2): 387-398.

Pastor J, Verdoit-Jarraya M, Astruch P, Dalias N, Nelva-Pasqual JB, Saragoni G, Lenfant P (2009) Acoustic telemetry survey of the dusky grouper (Epinephelus marginatus) in the Marine Reserve of Cerbère - Banyuls: implications on the territoriality of this emblematic species. $\mathrm{Cr}$ Biol 332: 732-740

Pelaprat C (2000) Le cantonnement de pêche, un véritable outil de gestion ? Exemple du cantonnement de pêche de Calvi (Corse, Méditerranée nord-occidentale). Thèse, Université de Corse, Corte

Pérez-Jiménez A, Cardenete G, Hidalgo MC, García-Alcázar A, Abellán E, Morales AE (2012) Metabolic adjustments of Dentex dentex to prolonged starvation and refeeding. Fish Physiol Biochem 38 (4):1145-1157. doi:10.1007/s10695-011-9600-2

Pinnegar JK, Polunin NVC (2004) Predicting indirect effects of fishing in Mediterranean rocky littoral communities using a dynamic simulation model. Ecol Model 172:249-267. doi:http://dx.doi.org/10.1016/j.ecolmodel.2003.09.010

Pinnegar JK, Polunin NVC, Francour P, Chemello R, Harmelin-Vivien M, Hereu B, Milazzo M, Zabala M (2000) Trophic cascades in fisheries and protected area management of benthic marine ecosystems. Environ Conserv 27(2): 179-200

Pitcher TJ, Hollingworth CE (2002) Recreational fisheries: ecological, economic and social evaluation. Fish Aquat Resour S, 8 Blackwell Science: Oxford ISBN 0-632-06391-2 XIV:1-271

Prato G, Guidetti P, Bartolini F, Mangialajo L, Francour P (2013) The importance of high-level predators in Marine Protected Areas management: consequences of their decline and their potential recovery in the Mediterranean context. Advances Oceanog Limnol 4(2):176-193. http://dx.doi.org/10.1080/19475721.2013.841754

Quero J-C, Spitz J, Vayne J-J, Auby I, De Casamajor M-N, Leaute J-P, Marie F, Quinquis J (2009) Observations ichtyologiques effectuées en 2008. Ann Soc Sci Nat Charente-Maritime 9 (9):932-940

Quetglas A, Ordines F, Hidalgo M, Monserrat S, Ruiz S, Amores Ãn, Moranta J, Massuti E (2012) Synchronous combined effects of fishing and climate within a demersal community. ICES J Mar Sci. doi:10.1093/icesjms/fss181

Quinn II TJ, Deriso RB (1999) Quantitative Fish Dynamics. Oxford University Press, New York

Radujkovic B, Raibaut A (1989) Parasites des poissons marins du Montenegro: copepodes. Acta Adriat 30 (1/2):237-278

Radujkovic BM, Euzet L (1989) Parasites de poissons marins du Montenegro: Monogenes. In Faune des parasites de poissons marins des côtes du Montenegro (Adriatic sud) Radujkovic, BM \& Raibaut, A (édit) Acta Adriat 30 (1/2):51-135 
Raibaut A, Combes C, Benoit F (1998) Analysis of the parasitic copepod species richness among Mediterranean fish. J Marine Syst 15 (104):185-206

Ramos-Esplà AA, Bayle-Sempere JT (1990) Management of living resources in the Marine Reserve of Tabarca island (Alicante, Spain). Bulletin de la societe zoologique de france-evolution et zoologie 114 (4):41-48

Ramos-Esplà AA, Bayle-Sempere JT (1991) Estatuto del Dentex dentex (Linnaeus, 1758) en el Mediterraneo. In: CF Boudouresque, M Avon and V Gravez (Editors) Les Espèces Marines à Protéger en Méditerranée GIS Posidonie Publ, Fr,:238-244

Rigos G, Grigorakis K, Koutsodimou M, Gialamas I, Fountoulaki E, Nengas I (2012) Comparison of muscle fatty acid and vitamin composition between wild and farmed common dentex (Dentex dentex). J Biol Res-Thessalon 17: 26-32

Riutort JJ (1989) Premières estimation des captures et de l'effort de pêche déployé par les « petits métiers » sur le littoral nord-ouest de la Corse. Etude de la biologie des principales espèces cibles. Stareso/Rapport Région de Corse.

Rocklin D (2010) Des modèles et des indicateurs pour évaluer la performance d'aires marines protégées pour la gestion des zones côtières. Application à la Réserve Naturelle des Bouches de Bonifacio (Corse). Université Montpellier 2.

Rocklin D, Tomasini J-A, Culioli J-M, Pelletier D, Mouillot D (2011) Spearfishing Regulation Benefits Artisanal Fisheries: The ReGS Indicator and Its Application to a Multiple-Use Mediterranean Marine Protected Area. PLoS ONE 6 (9):1-11

Rooker JR, Alvarado Bremer JR, Block BA, Dewar H, de Metrio G, Corriero A, Kraus RT, Prince ED, Rodriguez-Marin E, Secor DH (2007) Life History and Stock Structure of Atlantic Bluefin Tuna (Thunnus thynnus). Res Fish Sci 15 (4):265-310. doi:10.1080/10641260701484135

Rueda FM, Martinez FJ (2001) A review on the biology and potential aquaculture of Dentex dentex. Rev Fish Biol Fisher 11:57-70

Sacchi J, Dimech M (2011) Report of the FAO EastMed Assessment of the Fishing Gears in Lebanon. . Scientific and Institutional Cooperation to Support Responsible Fisheries in the Eastern Mediterranean GCP/INT/041/EC - GRE - ITA/TD-09 Athens:1-53

Sacchi J, Le Corre G, Mortreux S (2010) La sélectivité du gangui à panneaux des côtes varoises : analyse comparative de l'application de la maille carrée de $40 \mathrm{~mm}$. http://archimerifremerfr/doc/00086/19685/

Sahyoun R, Bussotti S, Di Franco A, Navone A, Panzalis P, Guidetti P (2013) Protection effects on Mediterranean fishassemblages associated with different rocky habitats. J Mar Biol Assoc Uk 93(2): 425-435

Shelton AO, Mangel M (2011) Fluctuations of fish populations and the magnifying effects of fishing. PNAS 108 (17):7075-7080

Seytre C, Francour P (2009) The Cap Roux MPA (Saint-Raphaël, French Mediterranean): changes in fish assemblages within four years of protection. ICES J Mar Sci 66 (1):180-187. doi:10.1093/icesjms/fsn196

Simkiss K (1973) Calcium metabolism of fish in relation to ageing. In Bagenal (Eds), The Ageing of Fish Unwin Brothers, London:1-12

Stergiou K, Karpouzi V (2001) Feeding habits and trophic levels of Mediterranean fish. Rev Fish Biol Fisher 11 (3):217-254. doi:10.1023/a:1020556722822

Stobart B, Warwick R, González C, Mallol S, Díaz D, Reñones O, Goñi R (2009) Long-term and spillover effects of a marine protected area on an exploited fish community. Marine Ecology Progress Series 384:47-60

Stobart B, Alvarez-Barastegui D, Goni R (2012) Effect of habitat patchiness on the catch rates of a Mediterranean coastal bottom long-line fishery. Fish Res 129-130 (0):110-118

Stossich M (1905) Note distomatologiche 3. Boll Soc Adriat Sci Nat 22:211-227 
Suarez MD, Martinez TF, Abellan E, Arizcun M, Perez-Jimenez A, Hidalgo MC, Cardenete G (2009) The effects of the diet on flesh quality of farmed dentex (Dentex dentex). Aquaculture 288

(12):106-113. doi:http://dx.doi.org/10.1016/j.aquaculture.2008.11.007

Ternengo S, Levron C, Mouillot D, Marchand B (2009) Site influence in parasite distribution from fishes of the Bonifacio Strait Marine Reserve (Corsica Island, Mediterranean Sea). Parasitol Res 104 (6):1279-1287. doi:10.1007/s00436-008-1323-7

Tomas A, Martinez-Llorens S, Jover M (2009) The effect of dietary soybean meal on growth, nutrient utilization efficiency, and digestibility of juvenile common Dentex, Dentex dentex (Actinopterygii: Perciformes: Sparidae). Acta Ichtyol Pisc 39 ((1)): 19-25.

Tortonese E (1973) Check-list of the fishes of the north-eastern Atlantic and of the Mediterranean (CLOFNAM). Sparidae In: J-C Hureau and Th Monod (eds)Unesco, Paris vol. I:405-415

Turan C (2006) The use of otolith shape and chemistry to determine stock structure of Mediterranean horse mackerel Trachurus mediterraneus (Steindachner). J Fish Biol 69:165180. doi:10.1111/j.1095-8649.2006.01266.x

Trilles J (1994) Les Cymothoidae (Crustacea, Isopoda) du monde (Prodrome pour une faune). Stud $\operatorname{Mar}(1-2)(21 / 22): 1-288$

Tzanatos E, Dimitriou E, Katselis G, Georgiadis M, Koutsikopoulos C (2005) Composition, temporal dynamics and regional characteristics of small-scale fisheries in Greece. Fish Res 73 (12):147-158. doi:http://dx.doi.org/10.1016/i.fishres.2004.12.006

Tzanatos E, Somarakis S, Tserpes G, Koutsikopoulos C (2008) Catch length analysis, relation to minimum landing sizes and management implications from a Mediterranean small-scale fishery (Patraikos Gulf, Greece). Fish Res 93 (1-2):125-134. doi:http://dx.doi.org/10.1016/j.fishres.2008.03.003

Valle C, Bayle-Sempere J (2009) Effects of a marine protected area on fish assemblage associated with Posidonia oceanica seagrass beds: temporal and depth variations. J Appl Ichthyol 25: 537-544

Valls A, Gascuel D, Guénette S, Francour P (2012) Modeling trophic interactions to assess the potential effects of a marine protected area: case study in the NW Mediterranean Sea. Mar Ecol Prog Ser 456: 201-214

Vandeperre F, Pérez-Ruzafa A, Santos RS, Higgins R (2006) Fishery regimes in Atlanto-Mediterranean European Marine protected Areas. EMPAFISH project, Booklet $\mathrm{n}^{\circ} 2$

Vigliano FA, Quiroga MI, Nieto JM (2002) Adaptaciones metabólicas al ayuno y realimentación en peces. Rev Ictiol 10:79-108

Walther GR, Post E, Convey P, Menzel A, Parmesan C, Beebee TJC, Fromentin JM, Hoegh-Guldberg O, Bairlein F (2002) Ecological responses to recent climate change. Nature 416 (28 March 2002): 389-395.

Williams HH, MacKenzie K, McCarthy AM (1992) Parasites as biological indicators of the population biology, migrations, diet, and phylogenetics of fish. Rev Fish Biol Fisher 2 (2):144-176. doi:10.1007/bf00042882

Williams RE, Lester RJG (2006) Stock structure of Spanish mackerel Scomberomorus commerson along the Australian east coast deduced from parasite data. J Fish Biol 68 (8):1707-1712

Yamaguti S (1963) Copepoda and Brachiura of fishes. Interscience Publishers, New York:1104 pp Zischke MT (2012) A review of the biology, stock structure, fisheries and status of wahoo (Acanthocybium solandri), with reference to the Pacific Ocean. Fish Res 119-120 (0):13-22 


\section{$\underline{\text { Table captions }}$}

Table 1. Growth parameters of Von Bertalanffy equation estimated for Dentex dentex. Ltoo = theoretical maximum size, $\mathrm{TL}=$ total length, $K=$ growth rate, $t_{0}=$ age at which the length at age $t$ is theoretically equal to 0 , $\mathrm{M}=$ Male, $\mathrm{F}=$ Female, $\mathrm{M} / \mathrm{F}=$ Male and Female.

Table 2. Bibliographical review of the known parasites of Dentex dentex; geographical location, position of the parasites and references.

Table 3. Summary of the exploitation of Dentex dentex (abundance), according to the season, sizes class composition, different gear, main depth range of operations and habitat.

Table 4. Minimum landing sizes of Dentex dentex for commercial fishing in some Mediterranean countries. 
Table 1.

\begin{tabular}{|c|c|c|c|c|c|c|c|}
\hline Lt $\infty(\mathbf{c m})$ & $\begin{array}{l}\text { Length } \\
\text { type }\end{array}$ & $K$ & $t_{0}($ years) & Sex & Country & Locality & Citations \\
\hline 110.000 & $\mathrm{TL}$ & 0.077 & -2.304 & $\mathrm{M} / \mathrm{F}$ & France & Calvi & (Culioli 1986) \\
\hline 84.400 & $\mathrm{TL}$ & 0.100 & -2.854 & $\mathrm{M}$ & Spain & Mallorca & $\begin{array}{l}\text { (Morales-Nin and } \\
\text { Moranta 1997) }\end{array}$ \\
\hline 85.622 & $\mathrm{TL}$ & 0.102 & -2.874 & $\mathrm{~F}$ & Spain & Mallorca & $\begin{array}{l}\text { (Morales-Nin and } \\
\text { Moranta 1997) }\end{array}$ \\
\hline 95.051 & $\mathrm{TL}$ & 0.077 & -1.796 & $\mathrm{M}$ & Tunisia & $\begin{array}{l}\text { Tunisian } \\
\text { coasts }\end{array}$ & $\begin{array}{l}\text { (Chemmam- } \\
\text { Abdelkader et al. } \\
\text { 2004) }\end{array}$ \\
\hline 97.354 & $\mathrm{TL}$ & 0.072 & -1.933 & $\mathrm{~F}$ & Tunisia & $\begin{array}{l}\text { Tunisian } \\
\text { coasts }\end{array}$ & $\begin{array}{l}\text { (Chemmam- } \\
\text { Abdelkader et al. } \\
\text { 2004) }\end{array}$ \\
\hline 96.804 & $\mathrm{TL}$ & 0.073 & -1.892 & $\mathrm{M} / \mathrm{F}$ & Tunisia & $\begin{array}{l}\text { Tunisian } \\
\text { coasts }\end{array}$ & $\begin{array}{l}\text { (Chemmam- } \\
\text { Abdelkader et al. } \\
\text { 2004) }\end{array}$ \\
\hline
\end{tabular}


Table 2.

\begin{tabular}{|c|c|c|c|c|}
\hline Parasite species & Class & $\begin{array}{l}\text { Geographical } \\
\text { location }\end{array}$ & Position & Citations \\
\hline $\begin{array}{l}\text { Allopodocotyle } \\
\text { jaffensis } \\
\text { (Fischthal, 1980) }\end{array}$ & Digenea & France, Scandola & Posterior intestine & $\begin{array}{l}\text { (Bartoli et al. } \\
\text { 2005) }\end{array}$ \\
\hline $\begin{array}{l}\text { Aphallus rubalo } \\
\text { (Bray, 1986) }\end{array}$ & Digenea & France, Scandola & Duodenum, rectum & $\begin{array}{l}\text { (Bartoli et al. } \\
2005)\end{array}$ \\
\hline $\begin{array}{l}\text { Aphallus tubarium } \\
\text { (Rudolphi, 1819) }\end{array}$ & Digenea & France, Scandola & $\begin{array}{l}\text { Posterior intestine, } \\
\text { rectum }\end{array}$ & $\begin{array}{l}\text { (Bartoli and Bray } \\
\text { 1987; Bartoli et al. } \\
\text { 2005) }\end{array}$ \\
\hline $\begin{array}{l}\text { Cainocreadium } \\
\text { dentecis } \\
\text { Jousson \& Bartoli, } \\
2001\end{array}$ & Digenea & France, Scandola & $\begin{array}{l}\text { Pyloric caeca, } \\
\text { Duodenum, mid- } \\
\text { intestine }\end{array}$ & $\begin{array}{l}\text { (Jousson and } \\
\text { Bartoli 2001; } \\
\text { Bartoli et al. 2005) }\end{array}$ \\
\hline $\begin{array}{l}\text { Hemiurus communis } \\
\text { Odhner, } 1905\end{array}$ & Digenea & France, Scandola & Stomach & $\begin{array}{l}\text { (Bartoli et al. } \\
2005)\end{array}$ \\
\hline $\begin{array}{l}\text { Metadena depressa } \\
\text { (Stossich, 1883) }\end{array}$ & Digenea & France, Scandola & $\begin{array}{l}\text { Pyloric caeca, } \\
\text { Duodenum, mid- } \\
\text { intestine, } \\
\text { Posterior intestine }\end{array}$ & $\begin{array}{l}\text { (Bartoli and Bray } \\
\text { 1987; Bartoli et al. } \\
\text { 2005) }\end{array}$ \\
\hline $\begin{array}{l}\text { Pachycreadium } \\
\text { carnosum (Rudolphi, } \\
\text { 1819) }\end{array}$ & Digenea & France, Scandola & $\begin{array}{l}\text { Duodenum, mid- } \\
\text { intestine, } \\
\text { Posterior intestine }\end{array}$ & $\begin{array}{l}\text { (Bartoli et al. } \\
2005)\end{array}$ \\
\hline $\begin{array}{l}\text { Stephanostomum sp. } \\
\text { (Metacercariae) }\end{array}$ & Digenea & $\begin{array}{l}\text { Spain, } \\
\text { Balearic Islands }\end{array}$ & Gills & $\begin{array}{l}\text { (González et al. } \\
\text { 2004) }\end{array}$ \\
\hline $\begin{array}{l}\text { Lecithochirium } \\
\text { musculus } \\
\text { (Looss, 1907) }\end{array}$ & Digenea & Adriatic Sea & & $\begin{array}{l}\text { (Carreras-Aubets } \\
\text { et al. 2012) }\end{array}$ \\
\hline $\begin{array}{l}\text { Timoniella } \\
\text { imbutiforme } \\
\text { (Molin, 1859) }\end{array}$ & Digenea & Italy, Triest & Intestine & (Stossich 1905) \\
\hline $\begin{array}{l}\text { Microcotyle erythrini } \\
\text { Van Beneden \& } \\
\text { Hesse, } 1863\end{array}$ & Polyopisthocotylea & $\begin{array}{l}\text { Spain, } \\
\text { Balearic Islands }\end{array}$ & Gills & $\begin{array}{l}\text { (González et al. } \\
\text { 2004) }\end{array}$ \\
\hline
\end{tabular}




\begin{tabular}{|c|c|c|c|}
\hline $\begin{array}{l}\text { Cathucotyle } \\
\text { acanthura (Parona \& } \\
\text { Perugia, 1896) }\end{array}$ & Polyopisthocotylea & $\begin{array}{l}\text { Mediterranean } \\
\text { Sea }\end{array}$ & (Euzet et al. 1993) \\
\hline $\begin{array}{l}\text { Udonella caligorum } \\
\text { Johnston, } 1835\end{array}$ & Monopisthocotylea & $\begin{array}{ll}\text { Spain, } & \text { Gills } \\
\text { Balearic Islands } & \end{array}$ & $\begin{array}{l}\text { (González et al. } \\
\text { 2004) }\end{array}$ \\
\hline $\begin{array}{l}\text { Encotyllabe vallei } \\
\text { Monticelli, } 1907\end{array}$ & Monopisthocotylea & Montenegro & $\begin{array}{l}\text { (Radujkovic and } \\
\text { Euzet 1989; Euzet } \\
\text { et al. 1993) }\end{array}$ \\
\hline $\begin{array}{l}\text { Dinemoura producta } \\
\text { (Mueller, 1785) }\end{array}$ & Copepoda & $\begin{array}{ll}\text { Spain, } & \text { Gills } \\
\text { Balearic Islands } & \end{array}$ & $\begin{array}{l}\text { (González et al. } \\
\text { 2004) }\end{array}$ \\
\hline $\begin{array}{l}\text { Caligus dakari } \\
\text { Beneden, } 1892\end{array}$ & Copepoda & $\begin{array}{l}\text { Montenegro } \\
\text { Kotor }\end{array}$ & $\begin{array}{l}\text { (Radujkovic and } \\
\text { Raibaut 1989) }\end{array}$ \\
\hline $\begin{array}{l}\text { Caligus diaphanus } \\
\text { Von Nordmann, } \\
1832\end{array}$ & Copepoda & $\begin{array}{ll}\text { Spain, } & \text { Gills } \\
\text { Balearic Islands } & \end{array}$ & $\begin{array}{l}\text { (González et al. } \\
\text { 2004) }\end{array}$ \\
\hline $\begin{array}{l}\text { Clavella denticis } \\
\text { (Krøyer, 1863) }\end{array}$ & Copepoda & Montenegro & (Yamaguti 1963) \\
\hline $\begin{array}{l}\text { Clavellotis fallax } \\
\text { (Heller, 1865) }\end{array}$ & Copepoda & $\begin{array}{ll}\text { Spain, } & \text { Gills } \\
\text { Balearic Islands } \\
\text { Montenegro, } \\
\text { Kotor }\end{array}$ & $\begin{array}{l}\text { (Radujkovic and } \\
\text { Raibaut 1989; } \\
\text { Raibaut et al. 1998; } \\
\text { González et al. } \\
\text { 2004) }\end{array}$ \\
\hline $\begin{array}{l}\text { Colobomatus denticis } \\
\text { (Richiardi, 1877) }\end{array}$ & Copepoda & $\begin{array}{l}\text { Mediterranean } \\
\text { Sea }\end{array}$ & $\begin{array}{l}\text { (Raibaut et al. } \\
\text { 1998; Bailly 2012) }\end{array}$ \\
\hline $\begin{array}{l}\text { Caligus vexator } \\
\text { Heller, } 1865\end{array}$ & Copepoda & $\begin{array}{l}\text { Italy, Genoa } \\
\text { Montenegro, } \\
\text { Kotor }\end{array}$ & $\begin{array}{l}\text { (Brian 1906; } \\
\text { Radujkovic and } \\
\text { Raibaut 1989; } \\
\text { Raibaut et al. 1998; } \\
\text { Bailly 2012) }\end{array}$ \\
\hline $\begin{array}{l}\text { Parabrachiella } \\
\text { exigua } \\
\text { (Brian, 1906) }\end{array}$ & Copepoda & $\begin{array}{l}\text { Mediterranean } \\
\text { Sea }\end{array}$ & (Bailly 2012) \\
\hline $\begin{array}{l}\text { Ceratothoa parallela } \\
(\text { Otto, 1828) }\end{array}$ & $\begin{array}{l}\text { Eumalacostraca } \\
\text { Isopoda }\end{array}$ & $\begin{array}{l}\text { Mediterranean } \\
\text { Sea }\end{array}$ & (Trilles 1994) \\
\hline $\begin{array}{l}\text { Gnathia vorax } \\
\text { (Lucas, 1849, } \\
\text { praniza larvae) }\end{array}$ & $\begin{array}{l}\text { Eumalacostraca } \\
\text { Isopoda }\end{array}$ & $\begin{array}{ll}\text { Spain, } & \text { Gills } \\
\text { Balearic Islands } & \end{array}$ & $\begin{array}{l}\text { (González et al. } \\
\text { 2004) }\end{array}$ \\
\hline
\end{tabular}


Table 3.

\begin{tabular}{|c|c|c|c|c|c|c|c|c|c|c|c|}
\hline Geographic Area & Sampling strategy & Sampling techniques & Sampling year & 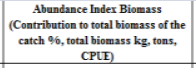 & 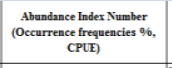 & Size class composition (cm) & $\begin{array}{c}\text { Slage of oflute and } \\
\text { capture }\end{array}$ & $\begin{array}{l}\text { Mhiin depth range } \\
\text { of operations (min) }\end{array}$ & Main manth actirity & Habiisat & Citations \\
\hline Crootia (Fastem.Adnaticic) & Landing & Tramata & |1986-99 & $2.9 \%$ & $0.22 \%$ & 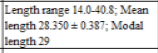 & Juvendes (By-catch) & 0.50 & July-September & & Cetinic et all 2002 \\
\hline Croostia (Nis) & Emperimental fisting & Trammel net & $1995-2009$ & & $1.7 \%$ & & & $0-40$ & & & Matí-Skoko et al 2011 \\
\hline France(Bonitiacio, MPA) & $\begin{array}{l}\text { Onboorar fishing } \\
\text { vessell zanding }\end{array}$ & Long line & $1992-93 ; 2000-066$ & :.7.7 kg 100 hooks & & & Target species & - & - & & Garmido 2007 \\
\hline France (Bonifacio, MPPA) & 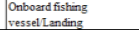 & Trammel net & $1092-93: 2000-0.06$ & 70 g $150 \mathrm{mof}$ of net $2 \mathrm{th}$ & - & & Target species & - & - & & Gararido 2007 \\
\hline France (Bonifacio, MP.A) & Onhoord fisting ves sel & Trammel net & $2004: 2006$ & 0.396 & & & Target species & & - & & Rocthin 2010 \\
\hline France (Bonifacio, MPA) & Onboard isishing ves sel & Irammel net & $2001 ; 2007$ & $4.04 \%(2001) ; 4.03 \% 6(2007)$ & & & Target specties & & & & Rochim 2010 \\
\hline France (Calk-Galeria) & Landing & Trarmenel net, long the & 1986 & $2=$ & - & Length range 14.74; Median 30 & 0 Jurentiles (By-catch) & & - & & Callibi 19966 \\
\hline $\begin{array}{l}\text { Francer (Corsica outside Scandola } \\
\text { PaA }\end{array}$ & Undernater risual census & SCUPA A diver & 1998 & $49 \mathrm{~g}_{110 \mathrm{~m}^{2}}$ & $0.08 \mathrm{ind} 1100 \mathrm{~m}^{2}$ & & - & $10-30$ & Jully & Rochy arteas & Francour 1991 \\
\hline France (Corsica Scandola MPA) & Underernater risual census & SclubA diver & $1990-2000$ & & 0.14 ind $100 \mathrm{~m}^{2}$ & & & 10.50 & June-August & Rocky areas & Francour 2004 \\
\hline Francer(Corsica Scandolata MPA) & Underexater visusul census & SCLBAA diver & 1998 & $19.1 \mathrm{~g}^{1} 10 \mathrm{~m}^{2}$ & 0.2 ind $110 \mathrm{~m}^{2}$ & & & 10.30 & Jully & Rochy areas & Francour 1901 \\
\hline France (Corrica) & Onboosd sampling & Trammen net, gill net & $2009 \cdot 10$ & 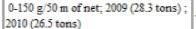 & & & Trarget species & & & & Francois 2011 \\
\hline France (Cóte Bleue, MPA & Landing & Iranmel net & $2009-10$ & & & & Target ppecies & 37.6 (mean value) & & & Ieleur 2012 \\
\hline Francer(Cros de Cagnes) & Landing & Iranmel net, long Iine & $2002-2005$ & $0.19 \% 6$ & & & & & & & Ieroy 2009 \\
\hline France (Itaverci islands) & Onboard ísthing ves sel & Trammel net, long thine & $1992-93$ & $1316 \mathrm{~kg}(5.54$ 96) & $0.74 \%$ \% $(n=-45)$ & 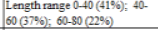 & Target species & - & - & & Culioin 1995 \\
\hline $\begin{array}{l}\text { France (National Partit of Port- } \\
\text { Cros) }\end{array}$ & Undererwater visual census & sclBA diver & 1989-1990 & $92.4 \mathrm{~g}_{10 \mathrm{~m}^{2}}$ & $0.4 \mathrm{in} d 100 \mathrm{~m}^{2}$ & & - & $10-30$ & Jume-September & Rocky areas & Francour 1992 \\
\hline 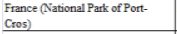 & Undernater visual census & SCLBA diver & $2005-2006$ & & $0.1 \mathrm{ind} 250 \mathrm{~m}^{2}$ & & - & 20,40 & ApprlJuly & Rocky areas & Francour 2007 \\
\hline $\begin{array}{l}\text { France (National Path of P Pott- } \\
\text { Cricos) }\end{array}$ & Landing & $\begin{array}{l}\text { Small.scale fisheries (all gears } \\
\text { coumbined) }\end{array}$ & 2005 & $1.30 \%$ & & & - & & & & Cadiou and Bonhomme 2006 \\
\hline France(Var) & Experinental fishing & Gangui & 2010 & & & & Juveniles (By-catch) & 15.35 & January-December & Posidania oceanaica meadiow & Sacchiet at 2010 \\
\hline France (Nart) & Onboord fishing vessel & Angling & $2010-2012$ & $14 \%$ & & & & & & & \begin{tabular}{|l|l|} 
Bodilis et al. 2012 \\
\end{tabular} \\
\hline $\begin{array}{l}\text { Francer(Nar,Cap Rour Fisheres } \\
\text { Reserve) }\end{array}$ & Experinental fisthing & Tramunel net & $2011-2012$ & & 0.3 ind 100 m of net (0.7796) & & - & $0+40$ & - & Rocky areas and Posidonia & Arceo 2012 \\
\hline France, Corsica (AW coast) & Landing & Tranmell net, long line & 1988-1989 & $3.6 \%$ & & & - & - & -- & & Rulitort 1999 \\
\hline Grocece & Declarative survey & $\begin{array}{l}\text { Small-scale fisheries } \\
\text { (all gears conbinted) }\end{array}$ & |1993-99 & 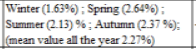 & & & & & Jaruary-December & & Tzenatos et al 2005 \\
\hline Greece(IKorintriakiks) & 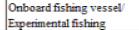 & Trammel net, gill net & $2008--99$ & & is & 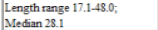 & - & - & June-September & & Moutop oullos et a a 2.2013 \\
\hline Greece(Patraikios) & Onboard fishing ves sel & Irammel net & 200405 & & & & Target spectes & $0-25$ & September-July & & Izzanatos et al 2008 \\
\hline Greece (Patraikos) & Oanbord fishing ves sel & Longline & 200405 & & & & Trasget species & 20.36 & March_November & & Tranatos et al 2008 \\
\hline 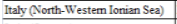 & Eperinentat lishing & Experimental bottam trawl & $1985-2008$ & & $0.0 \% \%$ & & & $\mid 15-258$ & & & Maiorano et a 1.2010 \\
\hline Italy (Otranto) & Underexater visual census & sctraA diver & 1997 & & $0.1 \pm 0.1$ ind $40 \mathrm{~m}^{2}$ & & & $6.5-5.0$ & & Seagrass snd Rochy - algal & Guideteti 2000 \\
\hline Lebenenen (Iyre) & Landing & 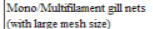 & $2005-06$ & & & & By-catch & & October-July & & Ielli etal 20066 \\
\hline 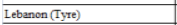 & Landing & Bottom longling & $2005-06$ & & & & Target specties & & January-December & & Ielli it it 20066 \\
\hline $\begin{array}{l}\text { Portugat (Setibalal and Sesimbran) } \\
\end{array}$ & Onboord fishing ves sel & Tranmenel nat & 200405 & $20.2 \mathrm{~g} 10.0000 \mathrm{~m}$ of net & & & Byy catch & & & & Batista et al. 2009 \\
\hline 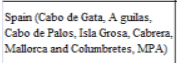 & Underwater risual census & SclBBA diver & 1996 & $6.9 \pm 3.8 \mathrm{~g} 250 \mathrm{~m}^{2}$ & $3.6 \pm 1.2 \min 250 \mathrm{~m}^{z}(18 \% \%)$ & & & 10 & & Rocky bottiom & Garcia-Chartion et at. 2004 \\
\hline Spain (Cabo de Palos, MPA) & 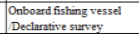 & Iranmel net & $2005-18$ & $6.6 \%$ & & & Target species & 30 (mean value) & Apprl-october & & Esperaza-Alarninos 2010 \\
\hline Spain, (Cabo de Palos, MPA) & 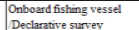 & Longline & $2005-08$ & 8.796 & & & Target speciess & & 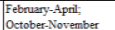 & & Esperra-Alaminos 2010 \\
\hline Spain (Caboo de Palos.MPA) & 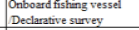 & Gillnet & $2005-08$ & 13.396 & & & Target species & & Febraxary-June & & Esperaz-Alaminos 2010 \\
\hline Spain (Call Ratijada, MPA) & Experimental fishing & Bottom long line & $2008-99$ & $450.5 \mathrm{~kg}(10.396)$ & $(\mathrm{n}=1500)$ & $\begin{array}{l}\text { Length range } 30-75 ; \text { Mean } \\
\text { length } 54\end{array}$ & & 31 (median) & & 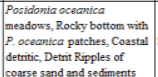 & Stobart te ta.12012 \\
\hline Sppin (Copp Creus, MPA) & Onboord fisthing vessed & $\begin{array}{l}\begin{array}{l}\text { Irammel net, gill net, long ine } \\
\text { basket traps }\end{array} \\
\end{array}$ & $2008-10$ & & & Meanlength $37.5 \mathrm{~cm}$ & & & & & Ilorect et all 2012 \\
\hline Spain (Cap Creus, MPRA) & Landing & Long line, gill net & 1991-2003 & $1 \%$ (1991-.98): $1.66 \%$ (1999-2003) & & & Target species & & $\begin{array}{l}\text { April.:November } \\
\end{array}$ & & Gomere et a a 2006 \\
\hline Spain (Columbretes Islands, MPA.), & 1) Experimental fishing & Trammel net & $1998-2006$ & & 0.461 ind 6000 m of net & & F- & 20.80 & & & Stobart te tal 2009 \\
\hline $\begin{array}{l}\text { Spain (Columbretes Ilalands, } \\
\text { Nearty fishery area of the NPA }\end{array}$ & Onboord dishing vessel & Trammel net & 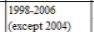 & & 0.10 Sind $600 \mathrm{~m}$ of net & & & $50-100$ & & & Stobarat te t1 12009 \\
\hline Spain (Denia) & Declarabive survey & 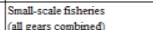 & $1995-2009$ & $2700 \mathrm{~kg}(2003): 5000 \mathrm{~kg}(2009)$ & & & - & & 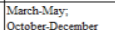 & & Orozcce et al 2011 \\
\hline Spain ('"Estartiti) & Undermater visual census & SCTBA diver & $1997-99$ & 696.0 og $10000 \mathrm{~m} 2(\mathrm{SD}=1391.9)$ & & & & 0.30 & & Gentity sloping rock & Macpherson et al 2002 \\
\hline Spain (Mvallorea) & Landing & Trammel net & 1093.95 & & & Length range 175.30 & Juventiles & & September-Narch & 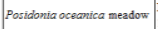 & $\begin{array}{l}\text { Morades-Nin and Moranta } \\
1997\end{array}$ \\
\hline Spain (Mallorra) & Landing & Long line & 1993-.95 & & & Lenght tange $17-83$ & Adult & & Appl-June & & $\begin{array}{l}\text { Morrales:Nin and Moranta } \\
1997\end{array}$ \\
\hline Spain (Santa Pola) & Declarative survey & Irawl & 1995-2009 & $2500 \mathrm{~kg}(20003) ; 5000 \mathrm{~kg}$ in (20099) & & & F & & March-May: & & Orozoce et all 2011 \\
\hline Spanin (Santat: Pola) & Declarestive survey & 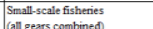 & $1905-2009$ & $7000 \mathrm{~kg}(2003) ; 19800 \mathrm{~kg}(20009)$ & & & & & $\begin{array}{l}\text { March-Mayy; } \\
\text { Otcober-December }\end{array}$ & & Orozce ettal 2011 \\
\hline Spain (Tabarca, MPA) & Underexatete visual census & 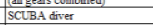 & $2005-06$ & 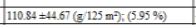 & & & & & & Posidalonia ocescanica meadow & Forcadd et al 2008 \\
\hline Spain (Tabarara, MPA) & Underexater visual census & SCUBA diver & $2005-06$ & $48625 \pm 200224(\mathrm{~g} / 125 \mathrm{~m}) ;(119090 \%)$ & & & - & & & Rocky bottom & Forcedda et al 2008 \\
\hline Spain(Tabaraca, MPAA) & Landing & Small tuap net (Morunass) & 1988-1989 & tess than $1 \%$ & & & - & & & & $\begin{array}{l}\text { Ramos-Esplia \& Bayle- } \\
\text { Sempere }\end{array}$ \\
\hline Spain (The Metes Islands, MPA.A) & Underwater visulal census & SctubA diver & $1997-99$ & 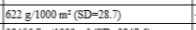 & & & & 0.30 & & Gently sloping rock & Macphetsson et a a L 2002 \\
\hline Spain (The Medes Islands. MPA) & Underexater visual census & SCUBA diver & $1997-99$ & $38456.7 \mathrm{~g} 10000 \mathrm{~m}^{\mathrm{z}}(\mathrm{SD}=3847.6)$ & & & & 0.30 & & Large broklen rocks & Macpherson ex al 2002 \\
\hline 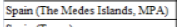 & Undersater visual census & ScuBA diver & $1997-.99$ & $3191.3 \mathrm{~g} / 1000 \mathrm{~m}^{2}(\mathrm{SD}=24.6)$ & & & & 0.50 & & Posidionia oceanica m & Macpherson et a a 2002 \\
\hline Spain (Tosss) & Underexater visual census & SctBA Adver & 1997.99 & $2136.5 \mathrm{~g} / 1000 \mathrm{~m}^{2}(\mathrm{SD}=372.9)$ & & & & 0.30 & & Gently sloping rock & Macpherson et a a 2002 \\
\hline 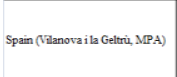 & Cabled video observatary & Digital inage scquisitions & $2000-10$ & & 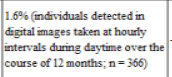 & & & 20 & May-Movember & Close to an antificial reef & Condal et at 2012 \\
\hline Turisia & \begin{tabular}{|l} 
Landing/D Dedarative \\
survey
\end{tabular} & Trammel net, gill net, long line & 1995-2002 & 301.484 tons & & Meann length 31.32 (1997-98) & 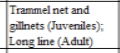 & & 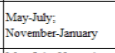 & & Cherrmamam 2004 \\
\hline Turisis & $\begin{array}{l}\text { Landing/ Declarative } \\
\text { survey }\end{array}$ & Irav1 & 1995-2002 & 27.643 tons & & Mean length 31.32 (1997-98) & & & $\begin{array}{l}\text { May,Jully: November. } \\
\text { January }\end{array}$ & & Chenrmam 2004 \\
\hline Turisisia & $\begin{array}{l}\text { landing Declarative } \\
\text { survey }\end{array}$ & $\begin{array}{l}\begin{array}{l}\text { Baskiet traps, traps net_ffike } \\
\text { net }\end{array} \\
\end{array}$ & 1995-2002 & 3259 tons & & Mean kength 31.32 (1997-98) & Jurendes (Dy-catch) & & \begin{tabular}{|l} 
Mays-July: \\
November-January
\end{tabular} & & Chenmemam 2004 \\
\hline Turisisi (Sounhem region) & Landing & Trammel Inet, long Inne, traxi & 2004 & & & 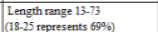 & Juveniles & & & & 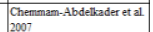 \\
\hline$\overline{T \text { Turiey (Antalya) }}$ & Landing & Bottom traswi net & 2009 & $16.5 \mathrm{~kg}^{\prime} \mathrm{mm}^{2}(\mathrm{SE}=5.92)$ & 248.8 ind $\mathrm{mm}^{2}$ & & & $25-200$ & Augugst & & 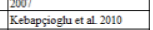 \\
\hline Turkey South of Irm & Landing & Beach stime & 1996 & & & & & & May-Septemb & & \begin{tabular}{|l|l|l|l|l|l|l} 
Alkyol 2003 \\
\end{tabular} \\
\hline
\end{tabular}


Table 4.

\begin{tabular}{|c|c|c|c|}
\hline Country & $\begin{array}{l}\text { Minimum } \\
\text { fish sizes } \\
\quad(\mathrm{cm})\end{array}$ & References & Citations \\
\hline Morocco & 12 & $\begin{array}{l}\text { Decree No. 1154-1188 of } 3 \text { October } 1988 \text { (as } \\
\text { amended and supplemented by decree No. } \\
352-89 \text { dated } 2 \text { February } 1989 \text {, by decree No. } \\
652-92 \text { of } 1 \text { October } 1993 \text { and decree No. } 373- \\
01 \text { dated } 21 \text { February 2001), }\end{array}$ & (Cacaud 2002) \\
\hline Algeria & 15 & $\begin{array}{l}\text { Decree No. 04-86 of } 26 \text { Moharram } 1425 \\
\text { corresponding to } 18 \text { March } 2004 \text { fixing the } \\
\text { minimum market sizes of biological resources. }\end{array}$ & $\begin{array}{l}\text { Official Journal of the } \\
\text { Republic of Algeria } \\
(24 / 03 / 2004)\end{array}$ \\
\hline Mauritania & 15 & $\begin{array}{l}\text { Decree No. 2002-073 of } 1 \text { October } 2002 \\
\text { laying down general rules for the application } \\
\text { of Law No. 2002-025 of } 24 \text { January } 2000\end{array}$ & $\begin{array}{l}\text { Official Journal of the } \\
\text { Islamic Republic of } \\
\text { Mauritania } \\
(30 / 10 / 2002)\end{array}$ \\
\hline Turkey & 20 & $\begin{array}{l}\text { Act fisheries No. } 1380 \text { of March 22, } 1971 \text { as } \\
\text { amended, supplemented with fisheries } \\
\text { regulations No. } 22223 \text { of March 10, } 1995 \text { and } \\
\text { section } 15 \text { of circular No. 33/1 }\end{array}$ & (Cacaud 2003) \\
\hline Tunisia & 22 & $\begin{array}{l}\text { Decree of } 28 \text { September } 1995 \text { regulating the } \\
\text { practice of fishing is the main text of } \\
\text { application of Law No. } 94-13 \text { of January } 31 \text {, } \\
1994\end{array}$ & (Cacaud 2002) \\
\hline Albania & 25 & $\begin{array}{l}\text { Law No. } 7908 \text { of } 5 \text { April } 1995 \text { on fisheries } \\
\text { and aquaculture Regulations No. } 1 \text { of March } \\
\text { 26, } 1997\end{array}$ & (Cacaud 2003) \\
\hline Croatia & 30 & $\begin{array}{l}\text { Based on the Article } 48 \text { paragraph } 3 \text { bullets } 1 \text {, } \\
2 \text { and } 3 \text { of the Marine Fisheries Act (Official } \\
\text { Gazette No. 46/97). }\end{array}$ & (Martín and Kekez 2009) \\
\hline
\end{tabular}




\section{Figure caption}

Fig. 1 Global geographical range of Dentex dentex (updated from Bauchot and Hureau 1986; Morales-Nin and Moranta 1997; Bat et al. 2005; FAO 2012).

Fig. 2 Annual catch of common dentex for all nations (grey bars), for Spain and Italy, the two highest contributor nations (lines) and the other nations (lines; Albania, Croatia, Cyprus, Egypt, France, Greece, Latvia, Libya, Malta, Montenegro, Portugal, Romania, Serbia,Tunisia, Turkey, Yugoslavia SFR), for the years 19502010 (based on FAO 2012). 


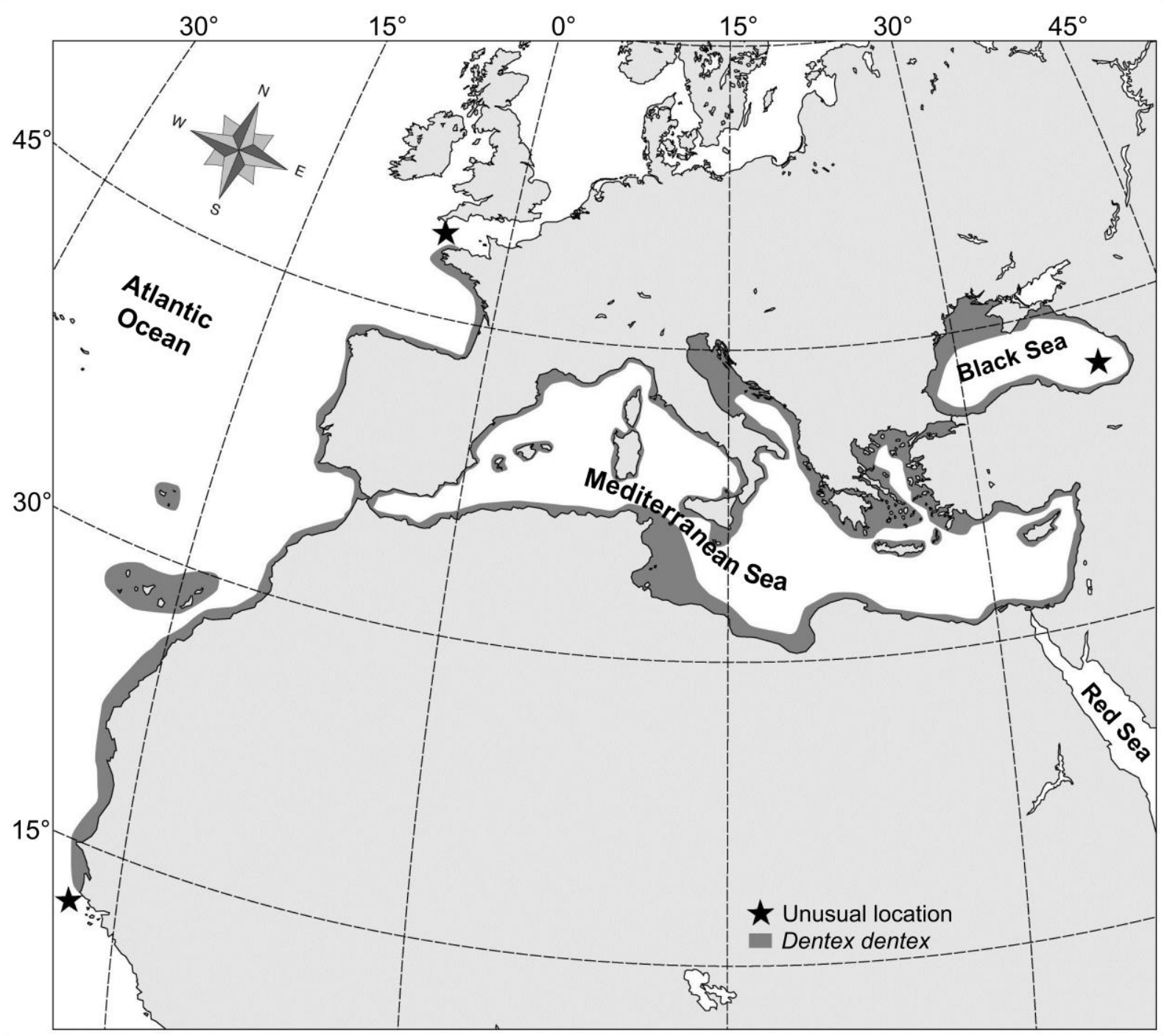

Fig. 1 


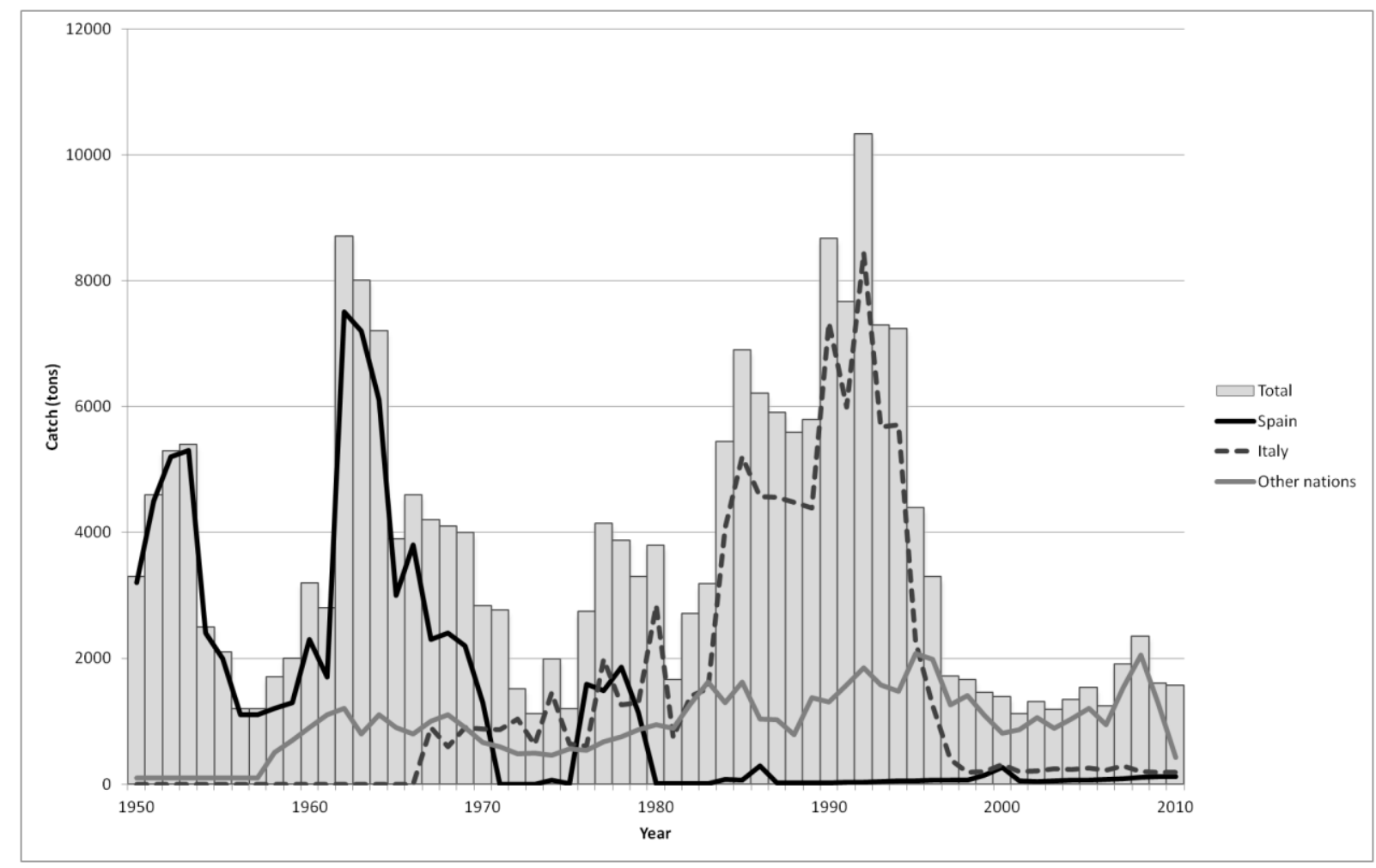

Fig. 2 